OPEN ACCESS

Edited by:

Shiv K. Gupta,

Mayo Clinic, United States

Reviewed by:

Liang Zhang

Mayo Clinic, United States

Sonia Jain

Mayo Clinic, United States

*Correspondence:

Shen Li

listenlishen@hotmail.com

tThese authors have contributed equally to this work

Specialty section

This article was submitted to Cancer Molecular Targets and

Therapeutics,

a section of the journal

Frontiers in Oncology

Received: 08 April 2020

Accepted: 08 July 2020

Published: 26 August 2020

Citation:

Huang R, Boltze J and Li S (2020) Strategies for Improved Intra-arterial Treatments Targeting Brain Tumors: a

Systematic Review.

Front. Oncol. 10:1443.

doi: 10.3389/fonc.2020.01443

\section{Strategies for Improved Intra-arterial Treatments Targeting Brain Tumors: a Systematic Review}

\author{
Rui Huang ${ }^{1}$, Johannes Boltze ${ }^{2 \dagger}$ and Shen $\mathrm{Li}^{1 * \dagger}$ \\ ${ }^{1}$ Department of Neurology, Dalian Municipal Central Hospital Affiliated With Dalian Medical University, Dalian, China, ${ }^{2}$ School \\ of Life Sciences, University of Warwick, Coventry, United Kingdom
}

Conventional treatments for brain tumors relying on surgery, radiation, and systemic chemotherapy are often associated with high recurrence and poor prognosis. In recent decades, intra-arterial administration of anti-cancer drugs has been considered a suitable alternative drug delivery route to intravenous and oral administration. Intra-arterial administration is believed to offer increasing drug responses by primary and metastatic brain tumors, and to be associated with better median overall survival. By directly injecting therapeutic agents into carotid or vertebral artery, intra-arterial administration rapidly increases intra-tumoral drug concentration but lowers systemic exposure. However, unexpected vascular or neural toxicity has questioned the therapeutic safety of intra-arterial drug administration and limits its widespread clinical application. Therefore, improving targeting and accuracy of intra-arterial administration has become a major research focus. This systematic review categorizes strategies for optimizing intra-arterial administration into five categories: (1) transient blood-brain barrier (BBB)/blood-tumor barrier (BTB) disruption, (2) regional cerebral hypoperfusion for peritumoral hemodynamic changes, (3) superselective endovascular intervention, (4) high-resolution imaging techniques, and (5) others such as cell and gene therapy. We summarize and discuss both preclinical and clinical research, focusing on advantages and disadvantages of different treatment strategies for a variety of cerebral tumor types.

Keywords: brain tumor, intra-arterial, targeted therapy, chemotherapy, blood-brain barrier, nanoparticles, superselective cerebral infusion, imaging

\section{INTRODUCTION}

Brain tumors are a large class of heterogeneous neoplasms, generally classified as benign or malignant tumors. It is widely believed that uncontrolled proliferation and tissue infiltration of dedifferentiated cells caused by harmful chemical, physical, and biological exposures are the main causes of brain tumor malignancy (1). Non-malignant brain tumors also can pose a much higher risk than elsewhere in the body, in particular when situated in areas hard to reach by surgical interventions. According to the latest statistics from the United States Central Brain Tumor Registry, the average annual incidence of brain and other central nervous system (CNS) tumors (malignant and non-malignant) after age adjustment was 23.03 per 100,000 people (2). Moreover, a worldwide meta-analysis reported that the total incidence of primary brain tumors was 10.82 per 100,000 person-years, with an estimated range of 0.01 (pineal tumors) to 25.95 (all primary brain tumors) per 100,000 people (1). As of 2011, several population-based studies indicated that the 
incidence of metastatic brain tumors was $7-14$ per 100,000 people (3), thus accounting for $2 \%$ of all cancers and $12.1 \%$ of metastatic diseases (4). The brain tumor incidence is related to a variety of factors, such as the type, location, and grade of a primary tumor in case of metastases, as well as the age, gender, ethnicity, and risk factor exposure of the patients $(1,5)$. For example, primary brain tumors are most common in children aged $0-14$ years $(2,6)$ and include hair cell astrocytoma, embryonic tumors, and malignant gliomas (6). Meningiomas have the highest incidence of all adult primary brain tumors (3), followed by malignant gliomas and pituitary tumors $(3,4)$. It is noteworthy that brain metastases are more common in adults, with lung cancer, breast cancer, and melanoma showing the highest rates $(3,4)$.

Brain tumors are relatively rare compared to other neurological diseases, and complex pathogenesis of some brain tumor types (especially malignant gliomas) often renders existing treatment strategies ineffective in prolonging survival time. Thus, brain tumors are the most life-threatening cancers in humans (7). The traditional treatment of brain tumors is the combination of surgery, radio- and chemotherapy (8). Surgery targets at the removal of tumor tissue. Radio- and chemotherapy as primary or adjuvant treatments have a positive effect on improving the survival rate of selected patients (9) and can reduce tumor mass prior to surgery. Anti-tumor effects are not only based on drug dose and tumor sensitivity but also related to the route of drug delivery. In general, drug binding to plasma proteins or lipids in the peripheral circulation and the target organ metabolism affect therapeutic effects after systemic administration (10). Systemic exposure in non-targeted organs caused by intravenous and oral administration are also an important factor restricting long-term use of chemotherapy drugs (11).

Intra-arterial administration was first described for the treatment of brain tumors in the 1950s (12). In comparison to intravenous delivery, intra-arterial administration increases intra-tumor drug concentration and accelerates systemic clearance (13). Up to now, intra-arterial administration has been shown to exert positive effects on recurrent or progressive malignant glioblastomas (14), retinoblastomas (15), and primary CNS lymphomas (16). However, severe vascular toxicity and neurotoxicity have been reported in several clinical studies. For example, patients with primary glioblastomas or anaplastic astrocytomas receiving intra-arterial cisplatin often experience significant loss in high-frequency hearing $(17,18)$. Moreover, patients with newly diagnosed or recurrent malignant gliomas or other brain tumors suffer from decreased visual acuity and irreversible encephalopathy (e.g., cerebral edema and leukoencephalopathy) when receiving intra-arterial carmustine 1,3-Bis(2-chloroethyl)-1-nitrosourea (BCNU) (19, 20). Myelosuppression mostly occurs in patients with primary CNS lymphomas who have received intra-arterial nitrosourea 1-(4-amino-2-methyl-5-pyrimidinyl)methyl-3-(2chloroethyl)-3-nitrosourea (ACNU) and radiotherapy (21). Myelosuppression is also the most common side effect of intraarterial cisplatin combined with oral etoposide in the treatment of recurrent malignant gliomas (22). Other relatively common complications include nausea, vomiting, thrombocytopenia, seizures, ocular pain, headache, intratumoral hemorrhage, transient cerebral ischemia, granulocytopenia, nephrotoxicity, and vasospasm (19, 21, 23-27). Radiotherapy before intraarterial administration may contribute to white matter necrosis $(20,28)$. Moreover, technical (e.g., perfusion strategy and artery selection) and pharmacological factors (e.g., drug dosage and compatibility) can affect safety, accuracy, and efficacy of intraarterial administration (29-31) and have not been discussed in detail so far.

On the other hand, a number of strategies to improve the therapeutic effects of intra-arterial administration for the treatment of brain tumors have been suggested. This systematic review summarizes the five most important ones. The first option is blood-brain barrier (BBB)/blood-tumor barrier (BTB) disruption using chemical reagents (such as mannitol, bradykinin, or alkylglycerols) or penetration drug carriers (such as liposomes, micelles, cell-penetrating peptides) to increase the direct entry of drugs into tumor and brain tissues. The second option is intra-arterial injection during transient cerebral hypoperfusion (IA-TCH) or flow arrest (IA-FA). This increases local plasma drug concentration and exposure time by reducing dilution, absorption, and contact with blood components. The third option are microcatheters designed to allow superselective intra-arterial cerebral infusion (SIACI) into the tumor-feeding arteries to reduce neurotoxic side effects while achieving welltargeted drug delivery. The fourth option is to combine imaging techniques, such as MRI, CT, X-ray, SPECT, and PET with intra-arterial infusion of labeled therapeutic agents, to monitor delivery and accumulation in the tumor and brain parenchyma. The fifth option is to use advanced techniques including intraarterial infusion of gene-edited viruses or cells to achieve targeted molecular or cell therapy for brain tumors. Next to providing an overview, this review also discusses advantages and limitations of these different strategies that became obvious in preclinical and clinical research.

\section{METHODOLOGICAL APPROACH}

Literature search and evaluation were conducted according to the Preferred Reporting Items for Systematic Reviews and MetaAnalysis (PRISMA) standard. No ex-ante protocol was used.

A systematic literature search was conducted in three databases: EMBASE, PubMed, and Web of Science. The original search date was October 22, $2019(n=1,835)$ and updated on June 30, $2020(n=1,855)$. One more study was included during the updated search. The publication time in EMBASE was 1963-2020, PubMed 1962-2020, and Web of Science 19462020. A keyword-based search strategy was applied as follows: In EMBASE, the keyword terms "brain tumor" and "intraarterial drug administration" of EMTREE dictionary were used. The $\mathrm{MeSH}$-defined keywords "Brain Neoplasms" and "Injections, Intra-Arterial" or "Infusions, Intra-Arterial" were used in PubMed searches, while Web of Science searches were conducted with "Brain tumor" and "Intra arterial." In addition, other eligible publications selected from the list of references in the included literature were used to supplement the search results. 
Only peer-reviewed articles published in English were included. The included literature should focus on strategies that aimed at improving the therapeutic effect of intra-arterial treatment. Therefore, articles that simply evaluated the therapeutic effects of intra-arterial administration but without comparing them to alternate approaches were excluded $(n=105)$. We also excluded conference abstracts $(n=10)$, papers without available full-text $(n=3)$, papers not reporting brain tumor treatment $(n=21)$, and in-vitro studies $(n=5)$, as well as studies not reporting intraarterial treatment $(n=4)$ or being focused on embolization only $(n=5)$. Reviews were also excluded $(n=28)$.

\section{RESULTS}

\section{Data Set}

A total of 1,855 articles were retrieved from EMBASE $(n=486)$, PubMed $(n=534)$, and Web of Science databases $(n=835)$. By screening the reference lists of the included papers, one more publication was added to the search results, resulting in a total of 1,856 articles. Screening for duplicates and their removal resulted in a total of 1,070 articles. We next screened titles and abstracts, obtaining 399 articles not meeting any exclusion criterion. Finally, 218 articles published between 1981 and 2020 were included after full-text evaluation (Figure 1A), what allowed us analyzing literature output in the previous four decades.

We then grouped articles according to the strategies described for optimizing intra-arterial administration of therapeutic agents to brain tumors. There were 94 studies focusing on BBB/BTB disruption, 24 on $\mathrm{TCH}, 39$ on SIACI, 33 on imaging-guided approaches, and 46 on other therapeutic agents and methods (Figure 1B).

As shown in Figure 1C, research on optimization strategies changes with the development of new technologies. The majority of studies focused on BBB disruption and were most frequently published 1991-2000 $(n=42)$. Numbers of studies focusing on BBB disruption gradually decreased from 2001. However, the number of publications on BBB disruption was still higher (2001-2010) than or equal to (2011-2020) the numbers of studies focusing on other strategies. Research on nanoparticles became a main research focus for improving $\mathrm{BBB} / \mathrm{BTB}$ penetration in the past decade (2011-2020). Several techniques emerging from medical physics were applied in preclinical research on TCH $(n=10)$. With the improvement of microcatheters, superselective infusion techniques gradually became a routine treatment option in 2011-2020 $(n=14)$. In parallel, realtime image-based monitoring became increasingly important for optimization of therapeutic procedures $(n=14)$.

\section{Strategies for Improved Intra-Arterial Drug Delivery to Brain Tumors BBB/BTB Disruption}

The $\mathrm{BBB}$ represents a major obstacle for CNS drug delivery (32). The anatomy of BBB, mainly composed of brain endothelial cells, astrocytes, and pericytes (33), has been well studied. The tight junctions of endothelial cells are the mainstay of the barrier structure (34), while transcellular carriers and cell surface receptors (35) allow the selective transport of nutrients and metabolites (36) across the BBB. Morphology and function of $\mathrm{BBB}$ often change under pathological conditions (37). It has been found that the $\mathrm{BBB}$ is damaged in primary tumors such as meningiomas (38), schwannomas (39), and high-grade gliomas (40), but this does not necessarily facilitate drug uptake (41). On the other hand, excessive BBB permeability increases the risk of cerebral edema (42). Therefore, reasonable and targeted changes in $\mathrm{BBB}$ permeability are critical to increase drug uptake while at the same time minimizing drug dose and adverse effects.

Some chemical agents have been shown to modify the BBB (Table 1). The hypertonic solution mannitol (80) draws water from endothelial cells into blood vessels, causing endothelial cell shrink. This impacts tight junctions, allowing drugs to pass the $\mathrm{BBB}(81,82)$. Reagents with comparable effects comprise arabinose (83) and hypertonic urea (84). To date, mannitol remains one of the most effective hyperosmotic solutions for transient BBB disruption. Mannitol is safe and well-tolerated in combination with intra-arterial chemotherapy (Table 2). The approach increases $\mathrm{BBB}$ permeability and thus facilitates the use of relatively large-sized antibodies (e.g., bevacizumab and cetuximab) for the treatment of malignant glioma $(100,101,107)$. It improves therapeutic effects of methotrexate and carboplatin on primary CNS lymphomas and cerebral metastases $(93,98)$. The risk for cognitive impairment was reduced when mannitolmediated $\mathrm{BBB}$ disruption was used together with radiotherapy in patients with germ cell tumors (113). A multi-center study also confirmed the benefits of intra-arterial chemotherapy with osmotic $\mathrm{BBB}$ disruption in enhancing the therapeutic response of primitive neuroectodermal tumors (94). By detecting ${ }^{99 \mathrm{~m}} \mathrm{Tc}$ glucoheptonate $(\mathrm{TcGH})$, SPECT scans confirmed BBB opening within $40 \mathrm{~min}$ after mannitol injection and returned to the steady state after $6-8 \mathrm{~h}$. This provides a wide time window for clinical applications (82). However, preclinical studies revealed that $\mathrm{BBB}$ disruption with mannitol is variable (114) and may cause an unexpected increase in transcapillary transport of anticancer drugs into healthy brain tissues $(45,115)$. In both humans and experimental animals (e.g., pigs and rats), focal motor seizures occur during BBB opening and last for several hours after termination of the procedure. The presence of highfrequency and high-amplitude electroencephalography (EEG) signals suggests that intra-arterial injection of mannitol through the anterior circulation may directly affect the motor cortex, regardless of the size and location of the tumor, or applied chemotherapy $(116,117)$. Other potential complications such as tachycardia and increased intracranial pressure as well as nausea, headache, and vomiting have been reported retrospectively (118). BBB disruption may also result in transient aphasia, hemiparesis, or even edema-induced intracranial herniation (94). Some conditions can affect mannitol-mediated BBB opening (114). For example, low brain temperature and the $\mathrm{Na}^{+} / \mathrm{Ca}^{2+}$ exchange blocker KB-R7943 enhance mannitol-mediated BBB opening (119), while intraperitoneal administration of magnesium sulfate attenuates mannitol effects (120). Thus, hyperosmotic mannitol infusion remains challenging and is hard to control, even though 
A

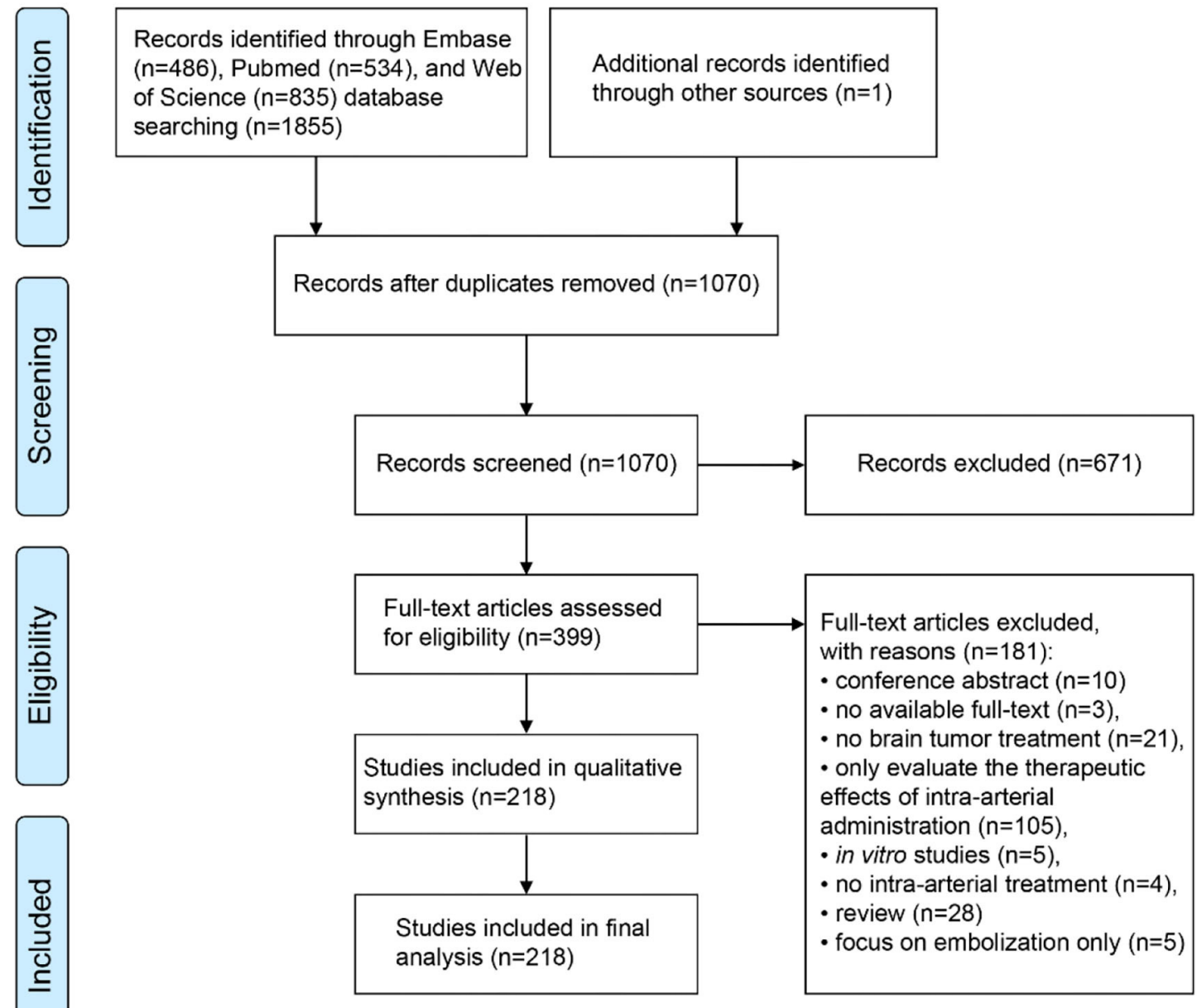

B

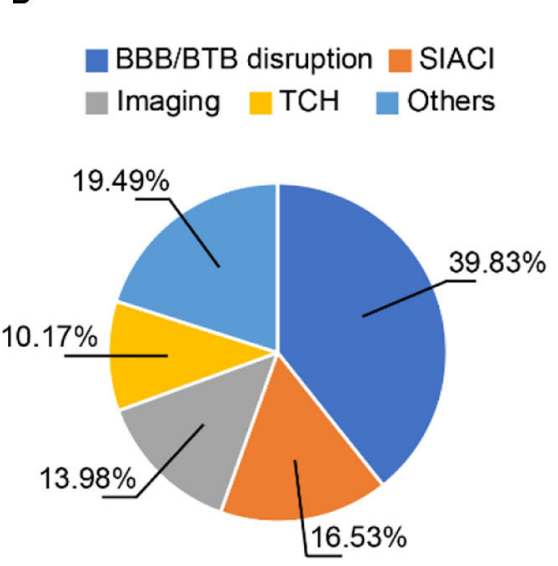

Total number of publications

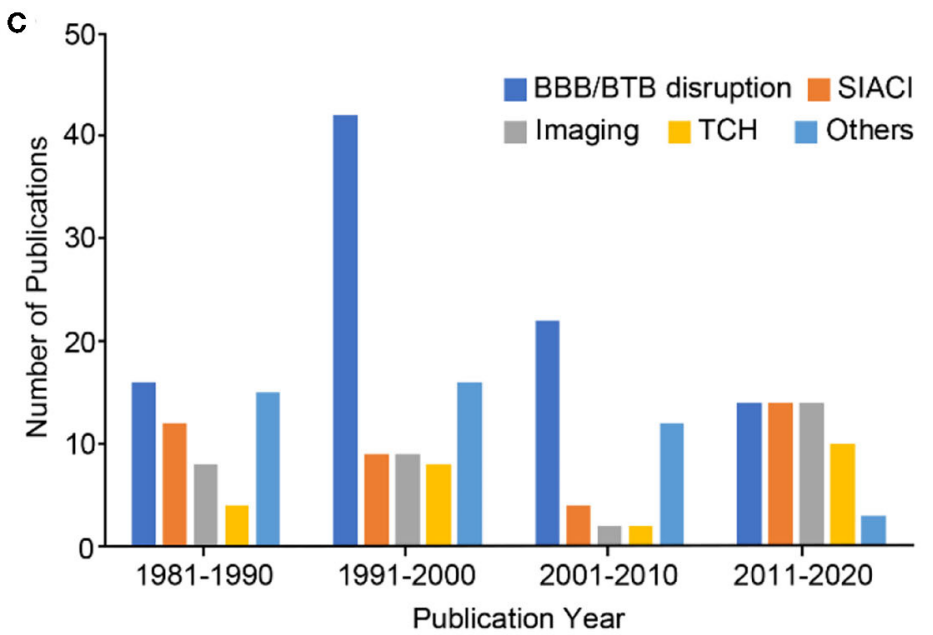

Number of publications per 10 years

FIGURE 1 | Methodological approach. (A) PRISMA flow diagram. (B) Pie chart of the total number of publications between 1981 and 2020 . (C) Temporal trend graph of the numbers of publications for different strategies. Since 1981, the numbers of articles on BBB/BTB disruption published in consecutive decades are 16, 42,22 , and 14, respectively. The numbers of articles on SIACI published in consecutive decades are 12, 9, 4, and 14, respectively. The numbers of articles on imaging published in consecutive decades are 8, 9, 2, and 14, respectively. The numbers of articles on TCH published in consecutive decades are 4, 8, 2, and 10, respectively. The numbers of articles on other strategies published in consecutive decades are $15,16,12$, and 3 , respectively. 
TABLE 1 | Agents for BBB modification: preclinical studies.

\begin{tabular}{|c|c|c|c|c|c|c|c|}
\hline No. & Agent & Concentration & Infusion velocity & Effect & Detection method & Model & References \\
\hline \multirow[t]{8}{*}{1} & Mannitol & $1.37 \mathrm{M}, 1.60 \mathrm{M}$ & $2.50 \mathrm{ml}$ over $30 \mathrm{~s}$ & $\begin{array}{l}\text { Capillary permeability } \uparrow \text {, cerebral blood } \\
\text { flow } \uparrow \text {, blood pressure } \uparrow\end{array}$ & ${ }^{14} \mathrm{C}-\mathrm{AlB},{ }^{14} \mathrm{C}$-IAP & $\begin{array}{l}\text { W256 carcinosarcoma and } \\
\text { C6 glioma-bearing rats }\end{array}$ & (43) \\
\hline & & $1.60 \mathrm{M}$ & $0.25 \mathrm{ml} / \mathrm{s} / \mathrm{kg}$ for $30 \mathrm{~s}$ & Survival of the rats $\downarrow$ & Methotrexate & $\begin{array}{l}\text { Osteogenic } \\
\text { sarcoma-bearing rats }\end{array}$ & (44) \\
\hline & & $1.40 \mathrm{M}$ & $3.00 \mathrm{ml}$ over $45 \mathrm{~s}$ & $\begin{array}{l}\text { BBB opening } \uparrow \text {, leakage of HRP into } \\
\text { tumors } \uparrow \text {, concentrations of EB, HRP in } \\
\text { the normal brain } \uparrow \text {, concentrations of } 5 \text {-FU } \\
\text { in serum, tumor and tumor-free brain } \uparrow\end{array}$ & EB, HRP, 5-FU & RG-C6 glioma-bearing rats & (45) \\
\hline & & $1.60 \mathrm{M}$ & $2.50 \mathrm{ml}$ over $30 \mathrm{~s}$ & $\begin{array}{l}\text { Concentrations, distribution in tumor and } \\
\text { cortex } \uparrow\end{array}$ & ${ }^{14} \mathrm{C}$-methotrexate & C6 glioma-bearing rats & (46) \\
\hline & & $1.60 \mathrm{M}$ & $\begin{array}{l}0.12 \text { or } 0.25 \mathrm{ml} / \mathrm{s} \text { for } \\
30 \mathrm{~s}\end{array}$ & $\begin{array}{l}\text { Tumor uptake of boron compounds } \uparrow \text {, } \\
\text { mean survival time of the rats } \uparrow\end{array}$ & $\mathrm{BSH}$ or BPA, EB, HRP & F98 glioma-bearing rats & $(47-52)$ \\
\hline & & $1.60 \mathrm{M}$ & $0.09 \mathrm{ml} / \mathrm{s}$ for $30 \mathrm{~s}$ & $\begin{array}{l}\text { Percentage of accessible tissue } \\
\text { space } \uparrow\end{array}$ & $\begin{array}{l}{ }^{14} \mathrm{C} \text {-AlB },{ }^{14} \mathrm{C} \text {-dextran } 70, \\
{ }^{14} \mathrm{C} \text {-methotrexate }\end{array}$ & $\begin{array}{l}\text { LX-I human small cell lung } \\
\text { carcinoma-bearing female } \\
\text { athymic nude rats }\end{array}$ & (53) \\
\hline & & not given & Not given & Survival time of the rats $\uparrow$ & monoclonal antibody BR96-DOX & $\begin{array}{l}\text { LX-I human small cell lung } \\
\text { carcinoma-bearing female } \\
\text { athymic nude rats }\end{array}$ & (54) \\
\hline & & $1.60 \mathrm{M}$ & $1.5 \mathrm{~g} / \mathrm{kg}$ & Perfusion territory and BBB disruption $\uparrow$ & SAA (DHB, SA, DHTA) & Sprague-Dawley rats & (55) \\
\hline 2 & Arabinose & $1.60 \mathrm{M}$ & $0.78 \mathrm{ml}$ over $30 \mathrm{~s}$ & BBB permeability $\uparrow$ & EB & Male Fischer 344 rats & (56) \\
\hline 3 & Bradykinin & $10 \mathrm{mg} / \mathrm{kg} / \mathrm{min}$ & $\begin{array}{l}53.3 \mu \mathrm{l} / \mathrm{min} \text { for } \\
15 \mathrm{~min}\end{array}$ & $\begin{array}{l}\text { Permeability in tumor capillaries } \uparrow \text {, blood } \\
\text { volume in tumor or brain tissue }=\end{array}$ & $\begin{array}{l}{ }^{14} \mathrm{C} \text {-AlB, }{ }^{14} \mathrm{C} \text {-sucrose, }{ }^{14} \mathrm{C} \text {-inulin, } \\
{ }^{14} \mathrm{C} \text {-dextran, EB, and HRP }\end{array}$ & $\begin{array}{l}\text { 9L gliosarcomas, C6 } \\
\text { gliomas and RG-2 } \\
\text { glioma-bearing rats }\end{array}$ & $(57,58)$ \\
\hline \multirow[t]{6}{*}{4} & RMP-7 & $0.1 \mathrm{mg} / \mathrm{kg} / \mathrm{min}$ & $53 \mu \mathrm{l} / \mathrm{min}$ for $15 \mathrm{~min}$ & $\begin{array}{l}\text { Permeability in tumor capillaries } \uparrow, \text { blood } \\
\text { volume in tumor or brain tissue }=\end{array}$ & $\begin{array}{l}{ }^{14} \mathrm{C} \text {-AlB, }{ }^{14} \mathrm{C} \text {-sucrose, } \\
{ }^{14} \mathrm{C} \text {-inulin, and }{ }^{14} \mathrm{C} \text {-dextran }\end{array}$ & RG-2 glioma-bearing rats & (59) \\
\hline & & $0.1 \mathrm{mg} / \mathrm{kg} / \mathrm{min}$ & $53 \mu \mathrm{l} / \mathrm{min}$ for $15 \mathrm{~min}$ & $\begin{array}{l}\text { Permeability in tumor capillaries } \uparrow \uparrow, \\
\text { permeability of normal brain capillaries } \uparrow \text {, } \\
\text { permeability of the vascular barriers to } \\
\text { hydrophilic compounds } \uparrow \text {, lipophilic drug } \downarrow\end{array}$ & $\begin{array}{l}{ }^{14} \mathrm{C} \text {-carboplatin, }{ }^{14} \mathrm{C} \text {-dextran, } \\
\text { and }{ }^{14} \mathrm{C} \text {-BCNU }\end{array}$ & $\begin{array}{l}\text { Female Fischer } 344 \text { and } \\
\text { Wistar rats }\end{array}$ & (60) \\
\hline & & $0.1 \mathrm{mg} / \mathrm{kg} / \mathrm{min}$ & $53 \mu \mathrm{l} / \mathrm{min}$ for $15 \mathrm{~min}$ & $\begin{array}{l}\text { Permeability in tumor capillaries } \uparrow \text {, survival } \\
\text { of the rats } \uparrow\end{array}$ & $\begin{array}{l}{ }^{14} \mathrm{C} \text {-carboplatin, and } \\
{ }^{14} \mathrm{C} \text {-dextran }\end{array}$ & RG-2 glioma-bearing rats & (61) \\
\hline & & $0.1 \mathrm{mg} / \mathrm{kg} / \mathrm{min}$ & $53 \mu \mathrm{l} / \mathrm{min}$ for $15 \mathrm{~min}$ & $\begin{array}{l}\text { Delivery of carboplatin to brain tumors } \uparrow \text {, } \\
\text { survival time of the rats } \uparrow\end{array}$ & ${ }^{14} \mathrm{C}$-carboplatin & RG-2 glioma-bearing rats & (62) \\
\hline & & $0.1 \mathrm{mg} / \mathrm{kg} / \mathrm{min}$ & $53 \mu \mathrm{l} / \mathrm{min}$ for $15 \mathrm{~min}$ & Cytokines delivery to brain tumors $\uparrow$ & $\begin{array}{l}{ }^{125} \text { I-IFN-gamma, TNF-alpha, and } \\
\text { interleukin-2 }\end{array}$ & RG-2 glioma-bearing rats & (63) \\
\hline & & $1.5 \mathrm{mg} / \mathrm{kg}$ & For $15 \mathrm{~min}$ & $\begin{array}{l}\text { Viral delivery to brain tumors } \uparrow \text {, normal } \\
\text { brain tissue }=\end{array}$ & $\begin{array}{l}\text { Herpes virus hrR3 encoding virus } \\
\text { thymidine kinase gene and the } \\
\text { lacZ reporter gene }\end{array}$ & 9L gliosarcoma-bearing rats & (64) \\
\hline 5 & Alkylglycerols & $0.01-0.3 \mathrm{M}$ & $6 \mathrm{ml} / \mathrm{min}$ for $12 \mathrm{~s}$ & $\begin{array}{l}\text { Methotrexate delivery to the brain and to } \\
\text { brain tumors } \uparrow\end{array}$ & Cisplatin, methotrexate & C6 gliomas-bearing rats & (65) \\
\hline 6 & 1-O-pentylglycerol & $300 \mathrm{mM}$ & $\begin{array}{l}6 \mathrm{ml} / \mathrm{min} \text { over } \\
12-15 \mathrm{~s}\end{array}$ & $\begin{array}{l}\text { Concentrations of ErPC in the brain tumor } \\
\uparrow \uparrow, \text { brain tissue adjacent to tumors } \uparrow\end{array}$ & ErPC & C6 gliomas-bearing rats & (66) \\
\hline
\end{tabular}




\begin{tabular}{|c|c|c|c|c|c|c|c|}
\hline No. & Agent & Concentration & Infusion velocity & Effect & Detection method & Model & References \\
\hline & & $200 \mathrm{mM}$ & $6 \mathrm{ml} / \mathrm{min}$ for $2 \mathrm{~min}$ & $\begin{array}{l}\text { Delivery of small and large compounds to } \\
\text { normal brain and brain tumors } \uparrow\end{array}$ & $\begin{array}{l}\text { Fluorescein sodium, RB } \\
\text { 200-albumin, FITC-dextran, } \\
\text { methotrexate }\end{array}$ & C6 gliomas-bearing rats & (67) \\
\hline & 1-O-pentylglycerol & $10-300 \mathrm{mM}$ & $53 \mu \mathrm{l} / \mathrm{min}$ for $15 \mathrm{~min}$ & $\begin{array}{l}\text { No signs of toxicity, delivery of } \\
\text { methotrexate to the brain } \uparrow\end{array}$ & Methotrexate & Male Wistar rats & $(68,69)$ \\
\hline & 2-O-hexyldiglycerol & $50-100 \mathrm{mM}$ & $53 \mu \mathrm{l} / \mathrm{min}$ for $15 \mathrm{~min}$ & $\begin{array}{l}\text { No signs of toxicity, delivery of } \\
\text { methotrexate to the brain } \uparrow\end{array}$ & Methotrexate & Male Wistar rats & $(68,69)$ \\
\hline 7 & Histamine & $1,10 \mathrm{mg} / \mathrm{kg} / \mathrm{min}$ & $1.5 \mathrm{ml} / \mathrm{h}$ for $10 \mathrm{~min}$ & $\begin{array}{l}\text { Regional tumor and brain capillary } \\
\text { permeability } \uparrow\end{array}$ & ${ }^{14} \mathrm{C}-\mathrm{AlB}$ & RG-2 glioma-bearing rats & (70) \\
\hline 8 & Nifedipine & $\begin{array}{l}0,0.1,1,5,10 \\
\mathrm{mg} / \mathrm{kg} / \mathrm{min}\end{array}$ & For $15 \min$ & Permeability in tumor capillaries $\uparrow$ & $\mathrm{EB}$ & Male Wistar rats & (71) \\
\hline 9 & Etoposide & $3.0-22.5 \mathrm{mg} / \mathrm{kg}$ & For $25 \mathrm{~min}$ & BBB permeability $\uparrow$ & ${ }^{99 m}$ Tc-DTPA, EB & Sprague-Dawley rats & (72) \\
\hline 10 & Cisplatin & $1,1.2,1.5 \mathrm{mg}$ & For $60 \mathrm{~min}$ & $\begin{array}{l}\text { BBB permeability } \uparrow \text {, local cerebral blood } \\
\text { flow }=\end{array}$ & ${ }^{14} \mathrm{C}$-AIB, ${ }^{18} \mathrm{~F}$ - fluoroantipyrine & Female Wistar rats & (73) \\
\hline 11 & Vinorelbine & $5-10 \mathrm{mg} / \mathrm{kg}$ & $4 \mathrm{ml} / \mathrm{kg}$ for $2 \mathrm{~min}$ & BBB permeability $\uparrow$ & $\mathrm{EB}$ & Sprague-Dawley rats & (74) \\
\hline 12 & Leukotriene C4 & $2.50 \%$ & $\begin{array}{l}53.3 \mu \mathrm{l} / \mathrm{min} \text { for } \\
15 \mathrm{~min}\end{array}$ & BBB/BTB permeability $\uparrow$ & ${ }^{14} \mathrm{C}$-AIB, $\gamma$-GTP & RG-2 glioma-bearing rats & (75) \\
\hline 13 & Leukotriene E4 & $5 \mu \mathrm{g} / \mathrm{ml}$ & $\begin{array}{l}53.3 \mu \mathrm{l} / \mathrm{min} \text { for } \\
15 \mathrm{~min}\end{array}$ & $\begin{array}{l}\text { Permeability in tumor capillaries } \uparrow, \\
\text { permeability of normal brain capillaries }=\end{array}$ & $\begin{array}{l}{ }^{14} \mathrm{C} \text {-AlB, }{ }^{14} \mathrm{C} \text {-sucrose, } \\
{ }^{14} \mathrm{C}-5 \text {-FU, and }{ }^{3} \mathrm{H} \text {-methotrexate }\end{array}$ & C6 glioma-bearing rats & (76) \\
\hline 14 & TNF-alpha & $\begin{array}{l}0,1,000, \\
10,000,100,000 \\
\text { IU }\end{array}$ & $\begin{array}{l}\text { for } 1,2,4,8 \text {, and } \\
16 \mathrm{~h}\end{array}$ & BBB permeability $\uparrow$ & Sodium fluorescein, EB-albumin & newborn pigs & (77) \\
\hline 15 & $\begin{array}{l}\text { Short-acting NO donor } \\
\text { (Proli/NO) }\end{array}$ & $10^{-2}-10^{-12} \mathrm{M}$ & For $30 \mathrm{~s}$ and $3 \mathrm{~min}$ & $\begin{array}{l}\text { BBB permeability } \uparrow \text {, long-term survival of } \\
\text { the rats } \uparrow\end{array}$ & $\begin{array}{l}{ }^{14} \mathrm{C} \text {-AlB, }{ }^{14} \mathrm{C} \text {-sucrose, } \\
{ }^{14} \mathrm{C} \text {-dextran, sodium nitrite, } \\
\text { carboplatin }\end{array}$ & C6 glioma-bearing rats & (78) \\
\hline 16 & Papaverine & $0.5 \mathrm{mg} / \mathrm{kg}$ & $\begin{array}{l}\text { For } 0.5,1,2,3 \text { and } \\
5 \mathrm{~h}\end{array}$ & BBB permeability $\uparrow$ & $\begin{array}{l}\text { Occludin, claudin-5, F-actin, } \\
\text { PKA, HSP7O }\end{array}$ & C6 glioma-bearing rats & (79) \\
\hline
\end{tabular}

AIB, aminoisobutyric acid; BBB, blood-brain barrier; BCNU, carmustine; BPA, boronophenylalanine; BSH, sodium borocaptate; BTB, blood-tumor barrier; DHB, 2,4-dihydroxybenzoic acid; DHTA, 2,5-dihydroxyterephthalic acid; DTPA, Diethylene triamine pentaacetic acid; DOX, doxorubicin; EB, Evans blue; ErPC, erucylphosphocholine; FITC, fluorescein isothiocyanate; HRP, horseradish peroxidase; HSP70, heat shock protein 70; IAP, iodoantipyrine; IFN, interferon; PKA, protein kinase A; RB 200, rhodamine B200; $\gamma$-GTP, gamma glutamyl transpeptidase; SA, sodium salicylate; SAA, salicylic acid analogs; TNF, tumor necrosis factor; 5-FU, 5-fluorouracil. 
TABLE 2 | Agents for BBB modification: clinical research and applications.

\begin{tabular}{|c|c|c|c|c|c|c|c|c|c|}
\hline No. & Agent & Tumor & $\begin{array}{l}\text { Intra-arterial } \\
\text { administration }\end{array}$ & Surgery & Radiation & $\begin{array}{l}\text { Systemic } \\
\text { chemotherapy }\end{array}$ & Analysis method & Effect & References \\
\hline \multirow[t]{12}{*}{1} & Mannitol (1 ml/s, $120 \mathrm{ml})$ & Glioblastoma & $\begin{array}{l}\text { 5-fluarouracil, } \\
\text { Adriamycin }\end{array}$ & $x$ & $x$ & $x$ & $\mathrm{CT}$ & Tumor mass size $\downarrow /=$ & (85) \\
\hline & Mannitol (8-10 ml/s, 30 s) & Glioblastoma & Methotrexate & $x$ & $x$ & $x$ & $\begin{array}{l}\text { Cox Proportional Hazards } \\
\text { Regression Model }\end{array}$ & Survival of the patients $\uparrow$ & (86) \\
\hline & Mannitol (25\%, 30 s) & $\begin{array}{l}\text { Malignant gliomas, primary CNS } \\
\text { Iymphoma }\end{array}$ & Methotrexate & $x$ & $x$ & $x$ & CT and ${ }^{99 m}$ Tc- SPECT & $\begin{array}{l}\text { Tumor area } \downarrow \text {, BBB/BTB } \\
\text { disruption } \uparrow\end{array}$ & (87) \\
\hline & Mannitol (20\%, 200 ml) & Brain metastasis & $\mathrm{ACNU}$ & & & & $\begin{array}{l}\text { Two- and one-compartment } \\
\text { open model, } \\
\text { high-performance liquid } \\
\text { chromatography }\end{array}$ & $\begin{array}{l}\text { ACNU levels in blood and tissue } \\
\uparrow\end{array}$ & (88) \\
\hline & Mannitol (8-10 ml/s, $30 \mathrm{~s})$ & Brain metastasis & Methotrexate & & & $x$ & $\begin{array}{l}\mathrm{CT} \text { and } \\
\text { 99mTc-glucoheptonate } \\
\text { radionuclide scans }\end{array}$ & BBB/BTB disruption $\uparrow$ & (89) \\
\hline & Mannitol (20\%, $200 \mathrm{ml})$ & Astrocytoma & $\mathrm{ACNU}$ & $x$ & $x$ & & $\begin{array}{l}\text { CT and high-performance } \\
\text { liquid ion exchange } \\
\text { chromatography }\end{array}$ & $\begin{array}{l}2 / 3 \text {-year survival rate of the } \\
\text { patients } \uparrow, A C N U \text { levels in blood } \\
\text { and tissue } \uparrow\end{array}$ & (90) \\
\hline & Mannitol (25\%, 27-30 s) & Astrocytoma, glioblastoma & Methotrexate & & & $\times$ & $\begin{array}{l}\text { Three-compartment model, } \\
\text { fluorescence polarization } \\
\text { immunoassay }\end{array}$ & $\begin{array}{l}\text { Methotrexate concentrations in } \\
\text { serum and urine } \uparrow, \text { methotrexate } \\
\text { half-life and cytotoxic } \\
\text { concentrations } \uparrow\end{array}$ & (91) \\
\hline & Mannitol (20\%, $50 \mathrm{ml})$ & $\begin{array}{l}\text { Malignant gliomas, brain } \\
\text { metastases }\end{array}$ & $\begin{array}{l}\mathrm{ACNU} \text { and } \\
\text { cisplatin }\end{array}$ & & $x$ & & CT & $\begin{array}{l}\text { Survival of the patients with } \\
\text { malignant gliomas }=\text {, with brain } \\
\text { metastases } \uparrow\end{array}$ & (92) \\
\hline & $\begin{array}{l}\text { Mannitol }(25 \%, 4-10 \mathrm{ml} / \mathrm{s} \text {, } \\
30 \mathrm{~s})\end{array}$ & $\begin{array}{l}\text { Primary CNS lymphoma, } \\
\text { primitive neuroectodermal tumor, } \\
\text { metastatic disease, germ cell } \\
\text { tumor, glioblastoma multiforme }\end{array}$ & $\begin{array}{l}\text { Carboplatin or } \\
\text { methotrexate }\end{array}$ & & & $\times$ & $\begin{array}{l}\text { MRI, CT, Karnofsky } \\
\text { performance status } \\
\text { evaluation }\end{array}$ & $\begin{array}{l}\text { Tumor volume } \downarrow \text {, median survival } \\
\text { times } \uparrow\end{array}$ & (93-95) \\
\hline & $\begin{array}{l}\text { Mannitol }(25 \%, 3-11 \mathrm{ml} / \mathrm{s} \text {, } \\
30 \mathrm{~s})\end{array}$ & $\begin{array}{l}\text { Primary CNS lymphoma, } \\
\text { primitive neuroectodermal tumor }\end{array}$ & $\begin{array}{l}\text { Carboplatin or } \\
\text { methotrexate }\end{array}$ & & & $x$ & $\begin{array}{l}\mathrm{CT},{ }^{99 \mathrm{~m}} \mathrm{TC} \text { - glucoheptonate } \\
\text {-SPECT }\end{array}$ & $\begin{array}{l}\text { Time course to closure of the } \\
\text { BBB disruption }\end{array}$ & (82) \\
\hline & $\begin{array}{l}\text { mannitol (25\%, 3-12 ml/s, } \\
30 \mathrm{~s})\end{array}$ & $\begin{array}{l}\text { Primitive neuroectodermal } \\
\text { tumors, medulloblastomas, germ } \\
\text { cell tumors }\end{array}$ & $\begin{array}{l}\text { Carboplatin or } \\
\text { methotrexate }\end{array}$ & & $x$ & $x$ & $\begin{array}{l}\text { Physical examinations, CT, } \\
\text { and/or MRI scans, } \\
\text { cerebrospinal fluid studies, } \\
\text { and ophthalmologic } \\
\text { evaluations }\end{array}$ & $\begin{array}{l}\text { Overall survival } \uparrow \text {, time to } \\
\text { progression } \uparrow \text {, and } \\
\text { neurocognitive function } \uparrow \text { of the } \\
\text { patients }\end{array}$ & (96) \\
\hline & $\begin{array}{l}\text { Mannitol }(25 \%, 3-12 \mathrm{ml} / \mathrm{s} \text {, } \\
30 \mathrm{~s})\end{array}$ & $\begin{array}{l}\text { Refractory anaplastic } \\
\text { oligodendroglioma and } \\
\text { oligoastrocytoma tumors }\end{array}$ & $\begin{array}{l}\text { Carboplatin and } \\
\text { melphalan }\end{array}$ & & & $x$ & $\begin{array}{l}\text { CT, MRI, audiologic, } \\
\text { ophthalmologic and } \\
\text { neuropsychologic } \\
\text { evaluations, tumor } \\
\text { response, duration of } \\
\text { response, and survival }\end{array}$ & $\begin{array}{l}\text { Adverse events } \downarrow \text {, tumor } \\
\text { response } \uparrow \text {. median } \\
\text { overall/progression-free survival } \\
\text { of the patients } \uparrow\end{array}$ & (97) \\
\hline
\end{tabular}




\begin{tabular}{|c|c|c|c|c|c|c|c|c|c|}
\hline No. & Agent & Tumor & $\begin{array}{l}\text { Intra-arterial } \\
\text { administration }\end{array}$ & Surgery & Radiation & $\begin{array}{l}\text { Systemic } \\
\text { chemotherapy }\end{array}$ & Analysis method & Effect & References \\
\hline & $\begin{array}{l}\text { Mannitol }\left(1,400 \mathrm{mg} / \mathrm{m}^{2}\right. \\
10 \mathrm{~min} \text { or } 25 \%, 30 \mathrm{~s})\end{array}$ & Primary CNS Iymphoma & Methotrexate & & & $x$ & $\begin{array}{l}\mathrm{CT} \text {, fluorescence } \\
\text { polarization immunoassay, } \\
\text { non-compartmental analysis }\end{array}$ & $\begin{array}{l}\text { Cerebrospinal fluid/serum ratio of } \\
\text { methotrexate } \uparrow, \text { overall response } \\
\text { rate } \uparrow, \text { median overall survival of } \\
\text { the patients } \uparrow \text {, median } \\
\text { progression-free survival of the } \\
\text { patients } \uparrow\end{array}$ & $(98,99)$ \\
\hline & $\begin{array}{l}\text { Mannitol }(25 \%, 4-6 \mathrm{ml} / \mathrm{s} \text {, } \\
30 \mathrm{~s})\end{array}$ & Primary CNS lymphoma & Carboplatin & & & $x$ & $\begin{array}{l}\text { DC-EEG, near-infrared } \\
\text { spectroscopy }\end{array}$ & $\begin{array}{l}\text { Lateralized DC-EEG response } \\
\text { from negative to positive shift } \uparrow \text {, } \\
\text { BBB disruption } \uparrow\end{array}$ & (16) \\
\hline & Mannitol $(20 \%, 60-90 \mathrm{ml})$ & $\begin{array}{l}\text { Glioblastoma multiforme, } \\
\text { astrocytoma, metastatic brain } \\
\text { tumor }\end{array}$ & Fluorescein & & & & $\begin{array}{l}\text { Cerebral fluorescein } \\
\text { micro-angiograms }\end{array}$ & $\begin{array}{l}\text { Transport of fluorescein into } \\
\text { tumors and normal brain tissue } \uparrow\end{array}$ & $(47)$ \\
\hline & $\begin{array}{l}\text { Mannitol }(25 \%, 5,10 \\
\mathrm{ml} / 120 \mathrm{~s})\end{array}$ & $\begin{array}{l}\text { Recurrent or progressive } \\
\text { malignant gliomas, malignant } \\
\text { brainstem gliomas }\end{array}$ & $\begin{array}{l}\text { Bevacizumab } \\
\text { (superselective) }\end{array}$ & & & & MRI & $\begin{array}{l}\text { Tumor area, volume, perfusion } \downarrow \text {, } \\
\text { progression-free survival of the } \\
\text { patients } \uparrow\end{array}$ & $(100-104)$ \\
\hline & Mannitol (25\%, $10 \mathrm{ml} / 120 \mathrm{~s})$ & $\begin{array}{l}\text { Recurrent glioblastoma } \\
\text { multiforme }\end{array}$ & $\begin{array}{l}\text { Bevacizumab, } \\
\text { cetuximab, } \\
\text { temozolomide } \\
\text { (superselective) }\end{array}$ & $x$ & $x$ & $x$ & MRI, PET & $\begin{array}{l}\text { Tumor size and }{ }^{18} \text { F-FDG uptake } \\
\downarrow\end{array}$ & (105) \\
\hline & Mannitol (25\%, $10 \mathrm{ml})$ & $\begin{array}{l}\text { Multiply recurrent pediatric } \\
\text { ependymoma }\end{array}$ & $\begin{array}{l}\text { Bevacizumab, } \\
\text { cetuximab } \\
\text { (superselective) }\end{array}$ & $x$ & $x$ & $x$ & MRI, PET & $\begin{array}{l}\text { Residual tumor size and activity } \\
\downarrow\end{array}$ & (106) \\
\hline & $\begin{array}{l}\text { Mannitol }(20 \%, 12.5 \\
\mathrm{ml} / 120 \mathrm{~s})\end{array}$ & Recurrent malignant gliomas & $\begin{array}{l}\text { Bevacizumab } \\
\text { (superselective) }\end{array}$ & & $x$ & $x$ & MRI & Tumor progression $\downarrow$ & (14) \\
\hline & $\begin{array}{l}\text { Mannitol }(20 \%, 12.5 \\
\mathrm{ml} / 120 \mathrm{~s})\end{array}$ & Recurrent malignant gliomas & $\begin{array}{l}\text { Cetuximab } \\
\text { (superselective) }\end{array}$ & & & & $\begin{array}{l}\text { Physical and neurological } \\
\text { examination, MRI }\end{array}$ & Safe and tolerated toxicity & (107) \\
\hline & $\begin{array}{l}\text { Mannitol (20\%, } 12.5 \\
\mathrm{ml} / 120 \mathrm{~s})\end{array}$ & Newly diagnosed glioblastoma & $\begin{array}{l}\text { Cetuximab } \\
\text { (superselective) }\end{array}$ & $x$ & $x$ & $x$ & MRI & $\begin{array}{l}\text { No evidence of tumor } \\
\text { progression or recurrence, less } \\
\text { complications (e.g., mild } \\
\text { headache) }\end{array}$ & (108) \\
\hline \multirow[t]{4}{*}{2} & $\begin{array}{l}\mathrm{RMP}-7 \text { (0.1, 0.3, } 1,3 \\
\mathrm{mg} / \mathrm{ml}, 1 \mathrm{ml} / \mathrm{min})\end{array}$ & Recurrent malignant gliomas & None & & $x$ & & ${ }^{68} \mathrm{Ga}$ EDTA-PET, MRI & $\begin{array}{l}\text { Transport of }{ }^{68} \mathrm{Ga} \text { EDTA into } \\
\text { tumors } \uparrow \text {, normal brain tissue } \\
\text {-tumor volume } \downarrow\end{array}$ & (109) \\
\hline & $\begin{array}{l}\text { RMP-7 (10, 30, 100, } 300 \\
n g / k g)\end{array}$ & Recurrent malignant gliomas & Carboplatin & & & & Gadolinium-enhanced MRI & Tumor volume $\downarrow$ & (110) \\
\hline & RMP-7 (300 ng/kg) & $\begin{array}{l}\text { Recurrent glioblastoma } \\
\text { multiforme, anaplastic } \\
\text { astrocytoma }\end{array}$ & Carboplatin & $x$ & & & MRI & $\begin{array}{l}\text { Tumor progression and survival } \\
\text { differ in patients with } \\
\text { hypervascular and hypovascular } \\
\text { tumors }\end{array}$ & (111) \\
\hline & RMP-7 (11,448 ng/m²) & $\begin{array}{l}\text { Glioblastoma multiforme, } \\
\text { adenocarcinoma, high-grade } \\
\text { astrocytoma, mixed anaplastic } \\
\text { glioma }\end{array}$ & Carboplatin & $x$ & $x$ & $x$ & MRI & $\begin{array}{l}\text { No obvious tumor mass } \downarrow \text {, safe } \\
\text { and tolerated neurological } \\
\text { complications }\end{array}$ & (112) \\
\hline
\end{tabular}


most side effects seem mild and can be controlled by medications $(98,102)$.

The BTB is found on tumor capillaries and can have a continuous non-fenestrated, continuous fenestrated or discontinuous phenotype (121). The surface receptor profile of BTB capillaries is more heterogeneous than that of normal capillaries $(41,122)$. Intra-arterial infusion of bradykinin (57), its analog RMP-7 (known as Cereport ${ }^{\circledR}$ or Lobradimil, a widely used adjuvant chemotherapy reagent) (59), 1-O-pentylglycerol (66), or calcium antagonists (71) into rats transplanted with different tumor cell lines significantly increases BTB permeability. However, blood volumes within the tumor or the surrounding brain remain unchanged (Table 1). RMP-7 penetrates the BTB by activating $\mathrm{B} 2$ receptors on endothelial cells (60), which seems to be regulated by the NO-cyclic GMP pathway $(123,124)$. Infusion of RMP-7 also enhances intra-arterial delivery of a therapeutic herpes simplex virus vector $(64,125)$ and tumor uptake of carboplatin $(61,126)$. Short-chain alkylglycerols promote delivery of methotrexate (68) (Table 2). In Fischer 344 rats with gliosarcoma, bradykinin fosters selective herpes simplex virus infection in multiple tumor foci and increases the absorption of single crystal iron oxide nanoparticles (127). Moreover, histamine has a selective effect on increasing BTB permeability that is mediated by $\mathrm{H} 2$ receptors (70). Animal experiments demonstrated that intracarotid infusion of leukotriene C4 (75) and E4 (76) increase BTB permeability, but do not affect normal brain capillaries. Preclinical evaluation of RMP-7 indicated a high efficacy in tumor uptake but minimal disturbance to normal tissues. It can, however, cause rapidly emerging side effects including hypotension, hypertension, abdominal pain, vasodilatation, headache, nausea, tachycardia, fatigue, and vomiting during intravenous infusion in a dose-dependent manner (128). RMP-7 may also cause leukopenia, nausea, thrush, cellulitis, urinary tract infection, hematuria, weakness, seizures, sensory loss, cortical blindness, oculomotor nerve palsy, and even ischemic stroke at the maximum intra-arterial infusion dose of $300 \mathrm{ng} / \mathrm{kg}$ $(110,112)$. However, the RMP-7-induced BBB/BTB permeability is transient and the barrier can spontaneously recover even during RMP-7 administration. This makes it difficult to define the optimal dosing and timing paradigm of RMP-7 in order to promote the maximum intratumoral concentration of chemotherapeutic agents $(129,130)$. Therefore, any potential beneficial effects from RMP-7-mediated drug delivery need to be confirmed in further clinical investigations.

Importantly, drugs used for tumor treatment may also exert effects on the BBB (Table 1). Intra-carotid infusion of vinorelbine into rats increases local BBB permeability at high doses (74), although recent data show much lower vinorelbine efficacy in brain vs. peripheral metastases (131). Cisplatin (73) and etoposide (72) were reported to open the BBB, and this effect precedes changes in local cerebral blood flow and necrosis. BBB opening may therefore be a sensitive indicator of cisplatin and etoposide neurotoxicity during intra-arterial administration (73). However, cisplatin is known for its acute gastrointestinal toxicity causing nausea and vomiting and can lead to myelosuppression (132). Etoposide has systemic side effects, including leukopenia, thrombocytopenia, and anemia when used with carboplatin (133). Another main obstacle that restricts further application of cisplatin and etoposide is their unknown mechanism. Whether the capability of these drugs to bypass the BBB is due to increased bradykinin release or P-glycoprotein expression in newly formed vessels (134) remains uncertain and requires future research.

Recently, it has been found that convection-enhanced delivery (CED) using catheters stereotactically inserted into brain tumors fosters drug delivery into these tumors and surrounding brain tissue by establishing a local positive pressure gradient (135). In contrast to diffusion-based concentration gradients, CED has advantages when applying compounds of high molecular weight because of a BBB bypass $(135,136)$. A main application of CED is the targeted delivery of cytotoxin to the tumor parenchyma or the surrounding tissues with encouraging results being reported for glioblastoma multiforme $(137,138)$. However, there is not yet convincing evidence for a benefit of CED in other chemotherapeutic paradigms even though preliminary experience is promising. In a F98 glioma rat model, CED of platinum-based drugs and liposomes increases drug accumulation in tumor tissue and extends the median survival time (139). CED of carboplatin has also been reported to have a sound therapeutic effect on glioblastomas in a Phase I clinical trial (140). However, there are a number of side effects caused by CED, such as headache, seizure, fever, nausea, vomiting, fatigue, erythema, and even liver enzyme perturbations and hematological changes $(141,142)$, which are related to the time and location of the treatment (143). Factors such as catheter reflux, leakage, or improper imaging guidance may lead to treatment failure (144).

Focused ultrasound is a novel non-invasive strategy for reversibly disrupting $\mathrm{BBB}$ tight junctions. Application of low frequency continuous wave ultrasound ( $\sim 10 \mathrm{~ms}$ bursts, $1 \mathrm{MPa}$ amplitude, $1 \mathrm{~Hz}$ frequency for 20-30 s intervals) generated wellcontrollable damage to tumor tissue, but minimal disturbance to surrounding healthy brain tissue (145). Microbubbles are standard ultrasound contrast agents and can help to create large shear microstreaming to open the capillary wall (146). Doxorubicin encapsulated in liposomes significantly accumulates in the rat brain after MRI-guided focused ultrasound with microbubbles (147) and has been investigated in a patient with high-grade glioma recently (148). Using the same strategy, focused ultrasound enhances the delivery of BCNU by intravenous administration to normal and C6 glioma-implanted rat brain tissue (149) as well as methotrexate to the rabbit brain (150). The most severe side effects are necrosis, febrile seizures, hemorrhage, and brain edema. Other complications include tolerable back pain and self-limiting headache (151, 152). Focused ultrasound may offer a promising method greatly improving local drug delivery after intra-arterial administration, but more evidence for clinical safety, efficacy, and feasibility is required.

The recent advent of nanotechnology has led to widespread nanoparticle applications in intra-arterial administration (Table 3). Due to the ability to pass through the BBB, some nanoparticles can be used for intra-arterial drug delivery (168). The cationic (positive) charge on their surface increases homing 
toward negatively charged tumor cell surfaces (169). It has been demonstrated that intra-arterial injection of paclitaxelloaded cationic, polymeric, and magnetic liposomes increases drug delivery to the tumor tissue (156). When combined with $\mathrm{BBB}$ disruption induced by focused ultrasound, intra-arterial liposome injection increases their deposition into tumor tissue of C6 tumor-bearing rats (158). Similarly, application of cationizable lipid micelles (163) with cationic short peptides such as the cell-penetrating trans-activator of transcription (TAT) was shown to increase the uptake of micelles (165) and can be used for selective drug delivery to gliomas. The translocation efficiency of nanoparticles is not only determined by surface charge. For instance, larger particles are more likely to adhere to the vessel wall, but the hydrodynamic resistance for BBB crossing is also increased (162). Other parameters such as shape, lipophilicity, and ligand density can affect effective BBB penetration of nanoparticles (170). More research is needed to optimize intra-arterial nanoparticles delivery protocols for future applications.

\section{$\mathrm{TCH}$}

The pharmacokinetic theory of intra-arterial drug administration suggests that a comparable tumor response can be obtained faster by intra-arterial than by intravenous administration due to the first pass effect. Regional slow blood flow can increase tissue drug levels and rapid systemic clearance (171). In a non-human primate model, phased pulsatile infusion during the diastole resulted in excellent distribution of the drug in blood (172). Intra-arterial drug administration during cerebral hypoperfusion promotes drug deposition in tumor and surrounding tissues, increases the contact time of drugs with tumor cells, and avoids non-targeted binding to plasma proteins (173). Hence, such improved methods increase drug concentrations in the tumor tissue while at the same time enabling reduction of the overall amount of drugs infused, mitigating potential side effects $(174,175)$.

Almost 30 years ago, it was shown that glucose reduces the $\mathrm{pH}$ of tumors by reducing blood flow, which in turn promotes thermochemotherapeutic effects (176). Various vasodilators such as adenosine (177), histamine (178), or iloprost (179) have been considered to alter regional cerebral blood flow in brain and tumor capillaries. Adenosine was shown to promote endovascular embolization during arteriovenous malformation by transient induction of hypotension (180). Taking advantage of this, a decrease in mean arterial blood pressure can be achieved by intravenous injection of adenosine, esmolol, and large doses of cold saline. When combined with bilateral carotid occlusion, cerebral blood flow measured by a laser Doppler probe would transiently drop to $10-20 \%$ for $30-40 \mathrm{~s}$ and completely recover within $5 \mathrm{~min}$ without inotropic support. This procedure allows intra-arterial injection of less mannitol to achieve BBB disruption lasting at least $60 \mathrm{~min}$ (174). It has been shown that TCH can improve the uptake of lipophilic drugs (e.g., BCNU) into rabbit brains without causing severe neuronal damage or abnormal EEG signals (181). In glioma-bearing rats, it was found that a combination of lowering cerebral blood flow and BBB opening increases the concentration of the chemotherapeutic drug (e.g., mitoxantrone) in glioma tissue more than 10 -fold as compared to the contralateral, tumor-free brain tissue. The treatment effect was reported to last for more than $4 \mathrm{~h}$ (175). Furthermore, TCH is sufficient to enhance early regional deposition of nanoparticles such as micelles (163-165) and liposomes (158-162) into tumor tissues. This provides a novel approach for targeted intra-arterial tumor therapy (Table 3).

Despite these promising findings, the translation of TCHpromoted intra-arterial drug administration to brain tumors into clinically applicable procedures is still not completed. Although the strategy has been validated in standardized animal models, tumor response and survival time after intraarterial drug administration in humans were not yet described. $\mathrm{TCH}$ has been widely used in neurosurgical procedures for the treatment of arteriovenous malformations and aneurysms, but drug distribution in tumor vessels is complex and blood flow might be variable. Moreover, a relatively high risk of systemic hypotension or regional low cerebral blood flow is a challenge for the clinical application of $\mathrm{TCH}$ in intra-arterial drug administration.

\section{SIACI}

In theory, primary brain tumors usually have a limited number of supplying arteries. This is advantageous when considering treatment by superselective intra-arterial infusion (182). However, since the ophthalmic artery originates from the internal carotid artery, drugs injected into the internal carotid artery also reach the eye, which can injure retinal ganglion cells and lead to temporary or permanent ocular complications (183) such as vision loss, vasculitis, and cataracts (184). Hence, it is reasonable to selectively inject into the main tumor-supplying arteries rather than infusing into major brain supplying vessels, such as the carotid or vertebral arteries (185). In clinical practice, the tip of a superselective catheter is usually placed in the A1 segment of the anterior cerebral artery, the M1 segment of the middle cerebral artery, or in the posterior communicating artery (182). Supraophthalmic carotid infusion became the preferred procedure to prevent drugs from entering the eye (184, 186-191). Flow-directed soft-tipped balloon or singlelumen catheters (188) with an extended tip (182-184) can be remotely controlled by hydraulic forces (189) and allow to maneuver even in extremely curved skull base vessels (184). It has been reported that supraophthalmic carotid chemotherapy can be used to treat malignant gliomas with low dose cisplatin and $\operatorname{BCNU}(182,191,192)$, and that the pharmacokinetic changes of ${ }^{11} \mathrm{C}$-BCNU are consistent with the metabolic changes captured by PET (185). In combination with external beam radiation therapy, supraophthalmic infusion of fluorouracil was reported to achieve acceptable median survival rates in anaplastic astrocytomas and glioblastomas (193). Superselective intra-arterial infusion of bevacizumab $(100,103)$ or cetuximab $(107,108)$ combined with mannitol-mediated BBB opening exerts profound anti-proliferative effects (194) and reduces tumor volume. The procedure was proven to be safe and effective in the treatment of brainstem gliomas (104) and multiply recurrent pediatric ependymoma (106) as well as vestibular schwannomas (195). However, it is still unclear whether 
TABLE 3 | Microparticles for BBB penetration: preclinical studies.

\begin{tabular}{|c|c|c|c|c|c|c|}
\hline No. & Microparticle & Combined technique & Detection method & Effects & Model & References \\
\hline 1 & $\begin{array}{l}\text { Cationic magnetic aminodextran } \\
\text { microspheres and neutral } \\
\text { dextran microspheres }\end{array}$ & Magnetic field of 0.6 Tesla & $\begin{array}{l}\mathrm{Fe}_{3} \mathrm{O}_{4} \text { magnetite atomic } \\
\text { absorption }\end{array}$ & $\begin{array}{l}\text { Magnetite concentrations in } \\
\text { tumor } \uparrow \text {, } \\
\text { and in non-target tissue } \downarrow\end{array}$ & $\begin{array}{l}\text { RG-2 glioma-bearing } \\
\text { rats }\end{array}$ & (153) \\
\hline 2 & $\begin{array}{l}\text { BCNU-loaded wafer and PLA } \\
\text { nanoparticles coated with } \\
\text { transferrin }\end{array}$ & None & $\begin{array}{l}\text { Transferrin X-ray photoelectron } \\
\text { spectroscopy, Bratton-Marshall } \\
\text { colorimetric assay and } \\
\text { zeta-potential analysis, } \\
{ }^{99 m} \text { TC-SPECT, Gd-DTPA-MRI }\end{array}$ & $\begin{array}{l}\text { Tumor growth } \downarrow \text {, average survival } \\
\text { time of the rats } \uparrow\end{array}$ & C6 glioma-bearing rats & (154) \\
\hline 3 & $\begin{array}{l}\text { (DSPE-mPEG2000-) } \\
\text { ferrociphenol-loaded lipid } \\
\text { nanocapsules }\end{array}$ & CED & MRI/MRS & $\begin{array}{l}\text { Survival time of the rats } \uparrow \text {, } \\
\text { accumulation of lipid } \\
\text { nanocapsules in the tumor zone } \\
\uparrow\end{array}$ & $\begin{array}{l}\text { 9L gliosarcoma-bearing } \\
\text { rats }\end{array}$ & (155) \\
\hline 4 & $\begin{array}{l}\text { Paclitaxel-loaded cationic } \\
\text { polymeric magnetic liposomes }\end{array}$ & Magnetic field of 0.5 Tesla & $\begin{array}{l}\text { High-performance liquid } \\
\text { chromatography }\end{array}$ & $\begin{array}{l}\text { Brain concentration of the } \\
\text { liposomes } \uparrow\end{array}$ & Sprague-Dawley rats & (156) \\
\hline 5 & $\begin{array}{l}\text { Cisplatin, oxaliplatin-loaded } \\
\text { liposomes }\end{array}$ & $\begin{array}{l}\text { BBB opening, gamma knife } \\
\text { irradiation }\end{array}$ & $\begin{array}{l}\text { MRI, inductively coupled plasma } \\
\text { mass spectrometry }\end{array}$ & $\begin{array}{l}\text { Accumulate of the liposomes in } \\
\text { brain tumors } \uparrow, \text { mean survival } \\
\text { time of the rats } \uparrow \text {, tumor control } \\
\uparrow\end{array}$ & $\begin{array}{l}\text { F98 } \\
\text { glioblastoma-bearing } \\
\text { rats }\end{array}$ & (157) \\
\hline 6 & Cisplatin-loaded liposomes & $\begin{array}{l}\text { CED, gamma knife } \\
\text { irradiation }\end{array}$ & $\begin{array}{l}\text { Inductively coupled plasma mass } \\
\text { spectrometry }\end{array}$ & $\begin{array}{l}\text { Maximum tolerated dose } \uparrow \text {, } \\
\text { median survival time of the rats } \uparrow \\
\text { accumulation of drugs in tumor } \\
\uparrow, \text { systemic toxicity } \downarrow\end{array}$ & $\begin{array}{l}\text { F98 } \\
\text { glioblastoma-bearing } \\
\text { rats }\end{array}$ & (139) \\
\hline 7 & Doxorubicin-loaded liposomes & $\begin{array}{l}\text { Focused ultrasound with } \\
\text { microbubbles }\end{array}$ & MRI, fluorometric assay & $\begin{array}{l}\text { Tissue concentration of } \\
\text { doxorubicin } \uparrow\end{array}$ & Sprague-Dawley rats & $(147)$ \\
\hline 8 & $\begin{array}{l}\text { Anionic, cationic, and } \\
\text { charge-neutral liposomes }\end{array}$ & Focused ultrasound, TCH & $\begin{array}{l}\text { Diffuse reflectance spectroscopy, } \\
\text { multispectral imaging, spatial } \\
\text { frequency-domain imaging }\end{array}$ & $\begin{array}{l}\text { Uptake of the liposomes by brain } \\
\text { tumor } \uparrow\end{array}$ & C6 glioma-bearing rats & $(158-161)$ \\
\hline 9 & $\begin{array}{l}\text { Large }(200 \mathrm{~nm}) \text { and small } \\
(60-80 \mathrm{~nm}) \text { fluorescent } \\
\text { dye-loaded liposomes }\end{array}$ & $\mathrm{TCH}$ & $\begin{array}{l}\text { Diffuse reflectance spectroscopy, } \\
\text { multispectral fluorescence } \\
\text { imaging }\end{array}$ & $\begin{array}{l}\text { Uptake of the liposomes by brain } \\
\text { tumor } \uparrow\end{array}$ & C6 glioma-bearing rats & (162) \\
\hline 10 & Cationizable micelles & $\mathrm{TCH}$ & Diffuse reflectance spectroscopy & $\begin{array}{l}\text { Uptake of the micelles by brain } \\
\text { tumor } \uparrow\end{array}$ & $\begin{array}{l}\text { 9L gliosarcoma-bearing } \\
\text { rats }\end{array}$ & (163) \\
\hline 11 & TAT & $\mathrm{TCH}$ & $\begin{array}{l}\text { Multispectral fluorescence } \\
\text { imaging }\end{array}$ & $\begin{array}{l}\text { Uptake of the TAT by brain tumor } \\
\uparrow\end{array}$ & $\begin{array}{l}9 \mathrm{~L} \text { gliosarcoma-bearing } \\
\text { rats }\end{array}$ & (164) \\
\hline 12 & $\begin{array}{l}\text { TAT-decorated and neutral } \\
\text { micelles }\end{array}$ & FA & Diffuse reflectance spectroscopy & $\begin{array}{l}\text { Deposition of both micelles in the } \\
\text { tumor and blood vessels } \uparrow\end{array}$ & $\begin{array}{l}\text { 9L gliosarcoma-bearing } \\
\text { rats }\end{array}$ & (165) \\
\hline 13 & $\begin{array}{l}\text { Magnetically-mediated retention } \\
\text { of iron oxide nanoparticles }\end{array}$ & $\begin{array}{l}\text { Magnetic field of } 0.15 \text { or } \\
0.35 \text { Tesla }\end{array}$ & $\begin{array}{l}\text { MRI, electron spin resonance } \\
\text { spectroscopy }\end{array}$ & $\begin{array}{l}\text { Nanoparticle accumulation in the } \\
\text { tumor } \uparrow\end{array}$ & $\begin{array}{l}9 \mathrm{~L} \text { gliosarcoma-bearing } \\
\text { rats }\end{array}$ & (166) \\
\hline 14 & $\begin{array}{l}\text { Heparin-coated } \\
\text { superparamagnetic } \\
\text { nanoparticles loading cationized } \\
\text { model protein } \beta \text {-galactosidase }\end{array}$ & Magnetic field of 0.35 Tesla & $\begin{array}{l}\text { MRI, } \beta \text {-galactosidase activity } \\
\text { spectrophotometry }\end{array}$ & $\begin{array}{l}\text { Nanoparticle accumulation in the } \\
\text { tumor } \uparrow \text {, exposure of normal } \\
\text { brain regions } \downarrow\end{array}$ & $\begin{array}{l}\text { 9L gliosarcoma-bearing } \\
\text { rats }\end{array}$ & (167) \\
\hline
\end{tabular}

CED, convection enhanced delivery; DSPE-mPEG2000, 1,2-Distearoyl-sn-glycero-3-phospho-ethanolamine-N-[methoxy-(polyethylene glycol)-2000]; FA, flow arrest; Gd-DTPA, gadolium-diethylenetriamine pentaacetic acid; PLA, poly(D,L-lactic acid); TAT, cell-penetrating trans-activator of transcription; TCH, transient cerebral hypoperfusion. 
long-term slow infusion or rapid bolus infusion is the more effective approach (182). It was recently shown that median progression-free survival of patients with recurrent glioblastoma receiving a single dose of SIACI $15 \mathrm{mg} / \mathrm{kg}$ bevacizumab and mannitol is comparable or even longer than that of those who received biweekly intravenous bevacizumab at $10 \mathrm{mg} / \mathrm{kg}$ (102). Moreover, side effects including epilepsy and headache indicate a need for careful dose adjustments in therapies relying on multiple administrations (102). Adverse events during invasive procedures further include nausea, bradycardia, vomiting, headache, and vascular complications such as asymptomatic subintimal tear, and even intracranial herniation, stroke, and cerebral hemorrhage. Thus, extensive experience in endovascular intervention is required to apply superselective intra-arterial drug administration (94, 133). Favorable results have been reported for a patient suffering from metastatic breast cancer. Skull and dura mater metastasis disappeared after repeatedly performed superselective intra-arterial administration of epirubicin into the right superficial temporal artery and the middle meningeal artery, combined with embolization of tumor-supplying vessels (196). Moreover, the median overall survival was effectively extended to 6 months in small-cell lung cancer patients with brain metastases receiving superselective intracranial arterial infusion chemotherapy (teniposide, ACNU, and carboplatin) (197) vs. 4-6 months of standard whole brain radiotherapy $(198,199)$. Therefore, carefully weighing beneficial outcomes vs. potential risks and adverse events is required for different brain tumor types. Additional comparison to system administration in further clinical trials is also warranted.

\section{Advanced Imaging Technology}

Advanced imaging technology is of great value for the diagnosis and treatment of brain tumors (Table 4). Originally, imaging technology was mainly used to detect the radioactivity of radiopharmaceuticals or contrast agents in order to reflect the distribution of drugs in tumor tissues. Later, imaging was used to guide the intra-arterial drug perfusion and to predict therapeutic effects. Dynamic PET imaging was first performed to determine the position of the superselective catheter by intraarterial injection of ${ }^{11} \mathrm{C}$-labeled $\mathrm{BCNU}$, and to predict clinical response by comparing ${ }^{11} \mathrm{C}$ radioactivity within the tumor after SIACI vs. intravenous infusion (185). Similarly, continuous PET scans were performed to quantify the pharmacokinetic advantage of ${ }^{13} \mathrm{~N}$-labeled cisplatin by calculating the time course of ${ }^{13} \mathrm{~N}$ activity in tumor and normal brain tissue (200). In addition, PET can distinguish between cerebral necrosis following supraophthalmic intra-arterial chemotherapy or radiotherapy (low metabolic turnover) and tumor recurrence (high metabolic turnover) using ${ }^{18} \mathrm{~F}$-fluorodeoxyglucose $\left({ }^{18} \mathrm{~F}\right.$ FDG) (201). Glucose metabolism was also measured by PET imaging to evaluate early treatment effects of intra-arterial administration of ACNU into glioblastomas and astrocytomas (202), as well as recombinant human tumor necrosis factor (TNF)-alpha in malignant astrocytomas (203). Another noninvasive method using radiopharmaceutical labeling to monitor drug biodistribution in tumors for assessing the effectiveness of intra-arterial chemotherapy is dynamic scintigraphic imaging with ${ }^{195 m}$ Pt-labeled cisplatin (206). Moreover, SPECT using ${ }^{99 \mathrm{~m}} \mathrm{Tc}$-hexamethyl-propyleneamine oxime (HMPAO) allows one to evaluate the cerebral distribution after either fast pulsatile or slow continuous supraophthalmic carotid infusion (186). Using ${ }^{99 \mathrm{~m}}$ Tc-hexakis-2-methoxyisobutyl-isonitrile (MIBI), SPECT can also assess changes in tumor MIBI uptake before and after radiochemotherapy (204).

The main limitation of SPECT and PET is the relatively low spatial resolution of these imaging modalities. CT is superior in this respect, has widespread availability, and is easier to apply. The permeability of blood vessels in brain tumors can be assessed in CT images by measuring iopamidol distribution in blood vessels and the extracellular fluid space (217). Angio-CT provides more accurate information on the vascular territory of the tumor than digital subtraction angiography (DSA), which aids intra-arterial chemotherapy of metastatic brain tumors (208). Superselective angio-CT was also shown to precisely define enlarged medullary veins in patients suffering from astrocytomas (207). Recently, direct-current (DC)-EEG was applied for realtime, non-invasive monitoring of $\mathrm{BBB}$ opening during clinical treatment of a primary CNS lymphoma by measuring low frequency oscillations of $0.01-0.15 \mathrm{~Hz}(16)$, but the accuracy of the procedure needs to be verified.

With the widespread availability of MRI, the intra-arterial administration of therapeutic drugs to brain tumors is further improved. Due to its high resolution and sensitivity, MRI has the ability to accurately assess the therapeutic response to the tumors. Magnetic resonance spectroscopy (MRS) is used to reveal intracellular $\mathrm{pH}$ changes after $\mathrm{BCNU}$ treatment for anaplastic astrocytomas or glioblastomas with alkalization in intra-arterial administration and acidification in intravenous chemotherapy (209). The reduction of phosphocreatine and phosphodiesters, indicating early metabolic changes after intraarterial treatment, can be visualized by MRS imaging and precedes apparent structural changes (210). Recently, proton MRS was successfully applied to detect a decreased total cholesterol (tCho)/ $\alpha$-naphtalene acetic acid (NAA) metabolite ratio. tCho is used as a marker for cell membrane breakdown and proliferation, while NAA indicates neuronal density and viability. The decreased tCho/NAA ratio was observed in two regions of interest (enhancing component and nonenhancing T2-hyperintense signal abnormality) after SIACI of bevacizumab in the treatment of recurrent grade IV glioblastoma (194). By measuring biochemical changes rather than detecting anatomical abnormalities, MRS avoids the non-specific reduction of MRI contrast enhancement by bevacizumab, while providing potential biomarkers of treatment efficacy (194). However, these preliminary studies lack a precise description of clinically meaningful endpoints, which are urgently needed for the longterm follow-up of larger patient populations to determine the correlation of early metabolic changes with treatment outcomes.

MRI usually determines the changes in tumor volume by measuring the size of the contrast-enhanced lesion. However, given that both recurrent tumors and therapeutic drugs may cause $\mathrm{BBB}$ destruction leading to heterogeneous enhancement and T2/FLAIR hyperintensity, MRI has limitations in distinguishing between tumor recurrence and long-lasting 
TABLE 4 | Imaging techniques for intra-arterial drug delivery.

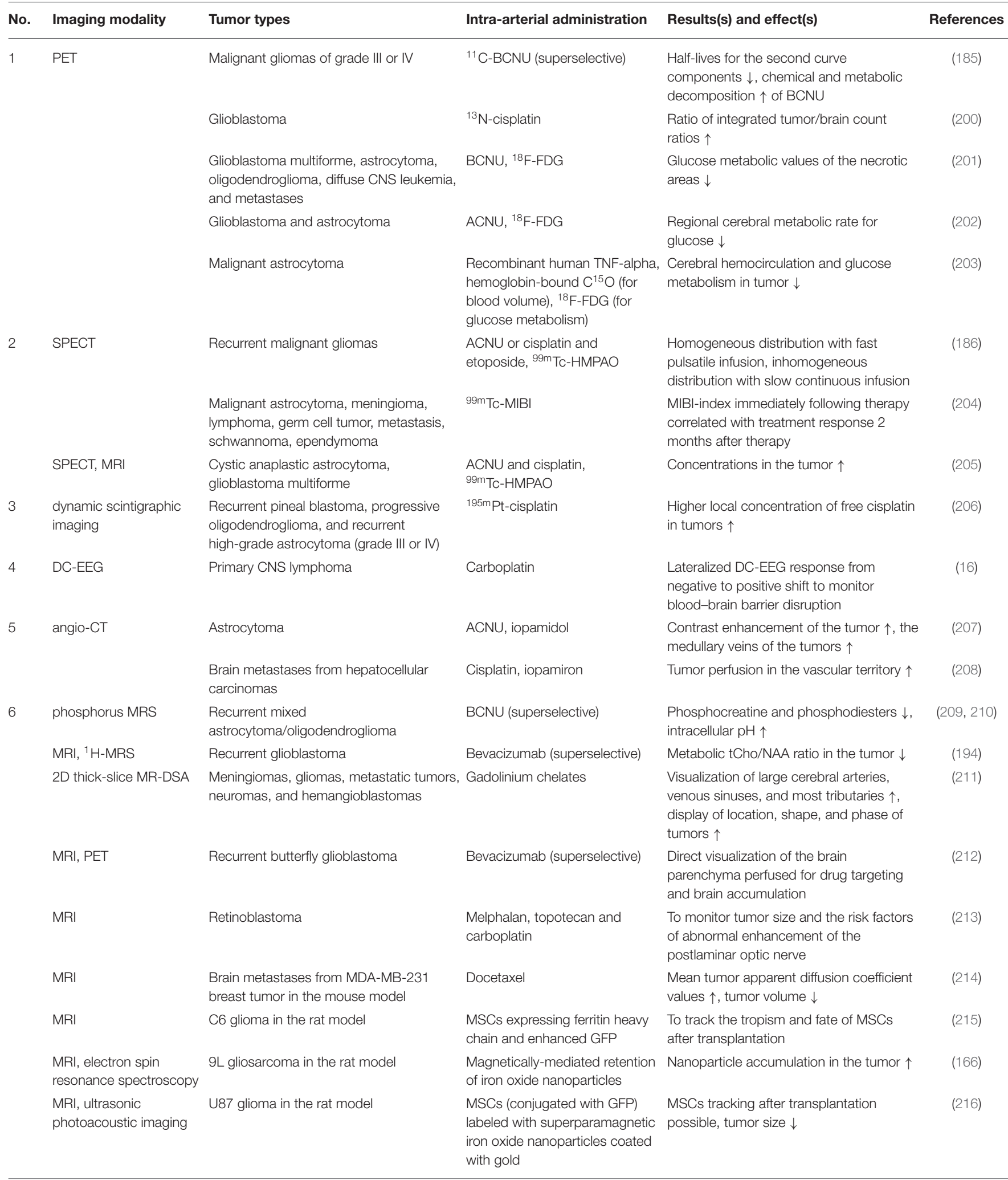

ACNU, nimustine; $B C N U$, carmustine; CNS, central nervous system; DC-EEG, direct-current electroencephalography; FDG, fluorodeoxyglucose; GFP, green fluorescent protein; HMPAO, hexamethyl-propyleneamine oxime; MIBI, hexakis-2-methoxyisobutyl-isonitrile; MSCs, mesenchymal stem cells; NAA, $\alpha$-naphtalene acetic acid; tCho, total cholesterol; TNF, tumor necrosis factor. 
sequelae of the therapeutic intervention. To overcome this deficiency, hemodynamic changes in tumors are considered an important indicator to accurately predict disease progression. Originally, MR DSA following bolus injection of gadolinium chelates offers a high temporal resolution for showing large cerebral arteries, venous sinuses, and tumor blood vessels. In some doubtful cases, MR DSA was able to identify meningioma and acoustic neuroma by first-pass stain. The tumors were later confirmed by pathological examination (211). Next, dynamic susceptibility contrast MR imaging (DSC-MRI) became a more common MRI perfusion technique. It can reveal cerebral blood volume, cerebral blood flow, and mean transit time for assessing brain tumors by using gadolinium-based tracer kinetic and dilution models (218). MRI with gadolinium was recently used to provide a better visualization of ambiguous tumor feeding arteries during microcatheter injection of bevacizumab in treating a recurrent butterfly glioblastoma, underlining the role of MRI in real-time guidance of neurointervention (212).

However, use of gadolinium-based agents is associated with a potential risk for brain deposition and nephrogenic systemic fibrosis (219). Chemical exchange saturation transfer (CEST), a new contrasting strategy, can apply a saturation pulse to the resonance frequency of the exchange protons on the compound to sensitively detect perfusion area and BBB opening. Salicylic acid analogs (SAA) are the natural contrast agents used for CEST MRI and may offer increased safety and operability than gadolinium-based agents (55). In recent years, 3D pseudocontinuous arterial spin labeling (3D-pcASL), a non-invasive MR perfusion measurement technique not requiring contrast injection, has been found to provide higher image quality with less susceptibility artifacts than DSC-MRI. Cerebral blood volume and flow measured by DSC-MRI or 3D-pcASL are different between patients with tumor recurrence and those who experience long-lasting treatment effects (220). However, image distortion still occurs in inhomogeneous regions. To address this, the combination of 3D-pcASL and Turbo Spin Echo using Cartesian acquisition with spiral profile reordering was used to provide better contrast between tumor and normal tissues. Another benefit is high reproducibility between scanning sessions, suggesting a potential use for therapeutic response assessment (221).

MRI monitoring and magnetic targeting also play an important role for intra-arterial drug delivery systems. A prominent example is highly selective deposition of magnetic microparticles in brain tumors (Table 3). In the late 1980s, large multivesicular liposomes containing magnetic resonance contrast agents were found to spontaneously attach to the vascular bed of vessels in the frontal and occipital lobe when injected intra-arterially into experimental animals (222). Currently, intravenously infused iron oxide nanoparticles can be selectively deposited in gliosarcomas when using a lowstrength magnetic field $(0.4 \mathrm{~T})$ (223). The short plasma half-lives of magnetic nanoparticles make them more suitable for intraarterial infusion (224). However, administering large numbers of magnetic particles into cerebral arteries is associated with a considerable risk of embolization (225). The precision of the approach can be increased by modifying magnetic field topography, thereby alleviating the above-mentioned risk of embolism (166). Further, the cationized model protein $\beta$ galactosidase (representing targeted protein drugs such as tumor suppressor proteins and anti-neoplastic enzymes) loaded onto heparin-coated iron-oxide nanoparticles could be precisely deposited in glioma tissue by intra-arterial infusion under MRI surveillance. This also allowed for optimization of magnetic field topography and maintained physiological arterial fluid dynamics, thus representing an effective approach for precise molecular treatment of brain tumors (167). In terms of cell transplantation, MRI enables real-time tracking of bone marrow-derived human mesenchymal stem cells (MSCs) labeled with superparamagnetic nanoparticles (216) or human MSCs expressing ferritin heavy chains (215) in experimental animals (Table 4). In addition, MRI may help to avoid adverse ischemic events in the clinical treatment of glioblastoma multiforme by intra-arterial infusion of tumor-infiltrating lymphocytes. This notion is supported by preclinical data showing that MRI is well-suited to evaluate ischemic events during intra-arterial infusion of activated $\mathrm{T}$ cells into the native rabbit brain (226).

\section{Other Approaches}

There are a number of other approaches to improve intraarterial administration. The first approach is the combination of compounds to enhance the efficacy of chemotherapeutic drugs. For instance, it was shown that the combination of oral $2 \% \mathrm{D}$, L-alpha-difluoromethylornithine and intra-arterial injection of BCNU doubled the median survival time of T9 gliosarcomabearing rats by reducing polyamine metabolism required for tumor growth and enhancing anti-tumor cytotoxicity of BCNU (227). Spirohydantoin mustard (spiromustine) promotes BBB penetration and cisplatin deposition in glioblastoma multiforme by combining the anti-tumor reactive moiety of cisplatin with the hydantoin part of spiromustine (228). However, the neurotoxicity of these compounds hampers the interest in further research.

The second approach is the combination of multiple therapeutic regimens. For example, intra-carotid administration of cisplatin combined with intravenous doxorubicin injection is an alternative treatment for patients with inoperable meningiomas (229). Short-term intra-arterial and intravenous chemotherapy prior to radiation increases survival of adult patients with astrocytomas (230). Hyperthermia enhances the cytotoxic effects and deposition of anti-cancer drugs to the tumors. Both preclinical and clinical studies showed that ACNU (231) or adriamycin $(232,233)$ delivery in combination with local or interstitial brain hyperthermia was associated with higher survival rates. Moreover, intra-arterial administration of carboplatin and melphalan combined with intrathecal topotecan chemotherapy showed a good alleviation effect on a patient suffering from extraocular retinoblastoma with CNS involvement (234). Of note, such combined therapy is often based on individualized treatments. This requires consideration of various factors such as radio- or chemotherapy sensitivity of the tumors, invasion area, and metastatic pathways.

The third approach is the use of new therapeutic agents. Injection of bromodeoxyuridine (anaerobic radiosensitizer) 
into the external carotid artery through a catheter has been found to increase susceptibility of glioma cells to radiotherapy and increases survival time of treated patients (235). Moreover, intra-carotid injection of recombinant human TNF and lymphotoxin produces remarkable anti-tumor effects in C6 and T9 gliomas-bearing animal models (236). Clinically, intraarterial administration of TNF-alpha improves the neurological symptoms in patients with glioblastoma multiforme or malignant astrocytomas by inducing coagulation necrosis in central tumor tissue and its feeding arteries (237). With the same strategy, advanced cytotoxins consisting of IL-13, IL-4 or transforming growth factor-alpha have been developed to target glioblastomas expressing these receptors $(144,238,239)$. In general, data regarding the efficacy of these cytotoxins is less encouraging when applied in solid tumors. This may be due to the difficulties of large molecules to penetrate the tumor mass, and lower or more variable receptor expression in solid neoplasms.

The fourth approach is gene therapy. Intra-arterial infusion of a p53-containing adenoviral vector can delay the growth of Gli36 glioblastoma tissue carrying a missense-mutated p53 gene (240). Phosphorothioate oligodeoxynucleosides injected intraarterially were precisely delivered to tumor tissue after BBB opening with bradykinin (241). Recently, intra-arterial infusion of a plasmid encoding an anti-angiogenic endostatin was shown to prolong survival time in the rat 9L gliosarcoma model by decreasing tumor vascular density, perfusion, and permeability (242). Moreover, G47Delta viruses (herpes simplex virus vector with oncolytic replication-competency) carrying deletions of the gamma34.5 and alpha47 genes (243) or the CLN2 gene (244) were injected into the carotid artery after mannitol-mediated $\mathrm{BBB}$ opening and had a positive impact on survival in a nude mouse model of cerebral breast cancer metastasis. A recent Phase II clinical trial showed that intra-arterial administration of ganciclovir combined with replication-deficient adenovirus mutant thymidine kinase is effective in improving 6-month progression-free survival, overall progression-free survival, and overall survival in patients with recurrent high-grade gliomas (anaplastic gliomas and glioblastomas) (245). Compared with intratumoral or intracerebral injections in current clinical trials $(246,247)$, intra-arterial gene therapy expands the treatment area and maximizes the therapeutic effect, but it also puts forward higher requirements for transfection efficiency.

The fifth approach is cell therapy that may benefit from intraarterial administration. Intra-carotid rather than intravenous

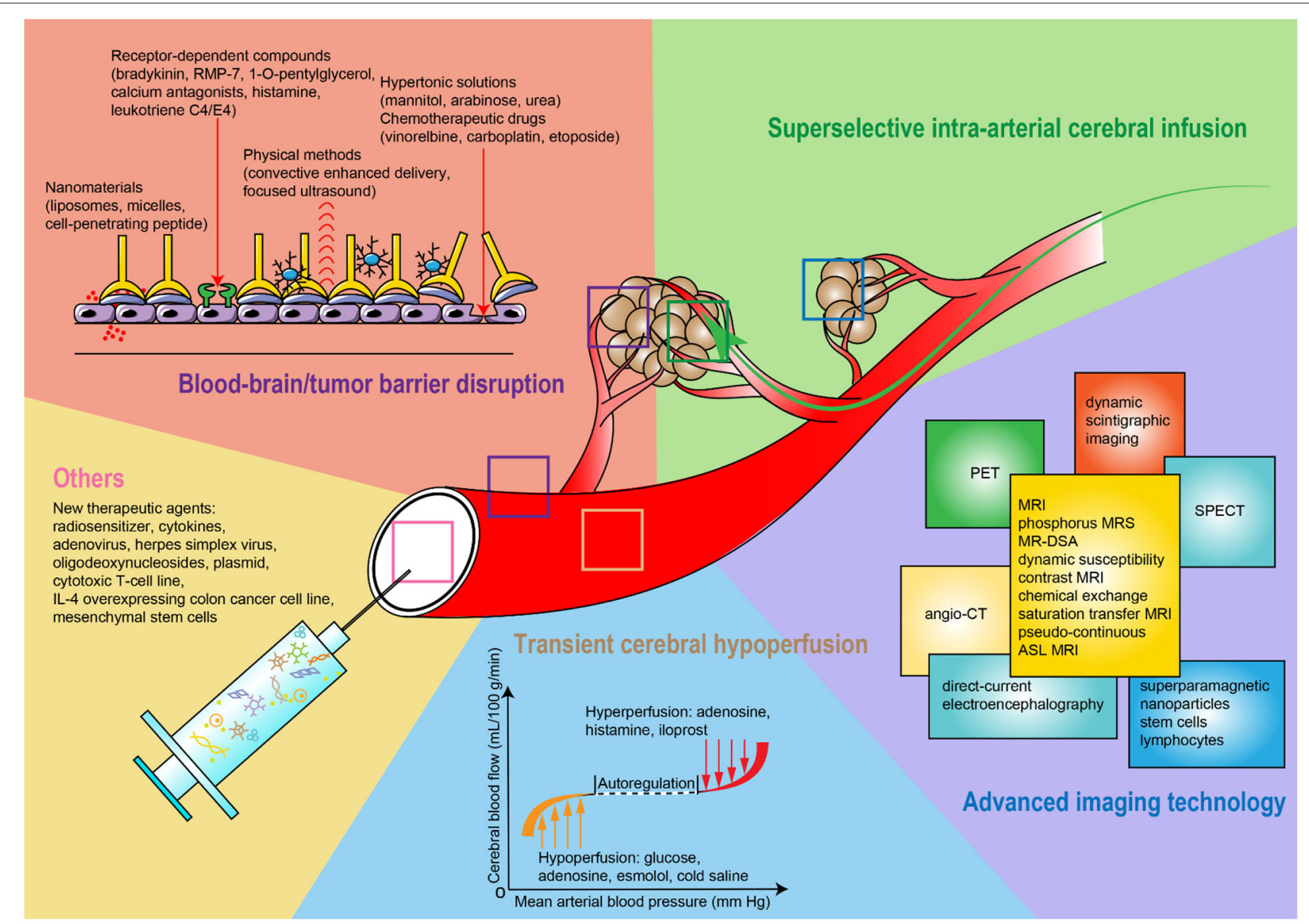

FIGURE 2 | Schematic diagram of strategies for improving intra-arterial administration. 
administration of a human cytotoxic T-cell line (TALL-104) in the 9L glioblastoma model and a metastatic xenograft model of epidermoid carcinoma enhanced specific anti-tumor effects and significantly prolonged survival time (248). Injection of a murine colon cancer cell line (CT-26) overexpressing interleukin-4 (IL4) or hemagglutinin antigen can serve as a pre-immunization strategy to prevent metastases from cecum, liver, and lung. Intracarotid but not systemic administration of CT-26 expressing IL4 or hemagglutinin antigen is effective to prevent the growth of blood-borne brain metastases (249). In addition, cells may be good "vectors" to be used in intravascular gene therapy. Human MSCs carrying Delta24-RGD oncolytic adenoviruses and labeled with green fluorescent protein are selectively planted into glioma xenografts and exert a strong anti-tumor effect (250). However, it is still too early to translate these approaches into clinical applications.

\section{CONCLUSIONS}

This systematic review comprehensively describes existing strategies for promoting the accuracy of intra-arterial drug delivery in experimental and clinical brain tumor therapy (Figure 2). These strategies show a promising potential to innovate and optimize many aspects of brain tumor treatments, including the accurate prediction of targeted tumor tissue, the effectiveness of drug transfer over the BBB/BTB, and the precise deposition of the therapeutic agent(s) in the tumor. Moreover, methodological advances foster the development of multidisciplinary treatment strategies that can result in better treatment effects and might represent a promising way forward in the treatment of brain tumors. However, translating new and improved methods from animal experiments to clinical practice still has to face many challenges. First, genetic, molecular, immune, and cellular differences between humans and other species prevent animal models from replicating the whole spectrum of important aspects of human pathophysiology under disease-specific conditions. Second, experimental animals exhibit different tolerances to drug toxicity, which makes it difficult to accurately assess the safety and effectiveness of therapeutic or adjuvant drugs before applying them to patients. Third, the number of patients included in early-stage clinical trials is usually insufficient to reveal all but the strongest effects, while patient age, sex, tumor type, course of disease, and adjunct treatment strategies are difficult to standardize or even harmonize. This limits the predictive value of obtained results. Based on this, new disease models have attracted much interest. The "tumor graft models" or "patient-derived xenograft" models are valuable humanized models to maintain the tumor heterogeneity and genetic characteristics of the patients by implanting tumor tissues removed from surgery into immunodeficient mice. Another breakthrough is the development of human brain organoids, which can be produced by patient-derived tumor cells or tissues in a 3D in-vitro culture system. These organoids have greater feasibility in large-scale screening of therapeutic agents and can exhibit their aggressiveness and proliferative ability and establish vascular system in host brains. In addition, some large animals exhibit an anatomical structure of the brain and its blood vessels being similar to that of humans, which may be a good option to optimize intraarterial procedures. These models can also make excellent use of clinical imaging technologies (251). Taken together, this forms an excellent basis to further refine intra-arterial approaches for the treatment of brain tumors to ultimately improve clinical treatment regimens.

\section{DATA AVAILABILITY STATEMENT}

All datasets generated and analyzed for this study are included in the article/supplementary material.

\section{AUTHOR CONTRIBUTIONS}

$\mathrm{RH}, \mathrm{JB}$, and SL defined the search strategy, conducted the literature search and review, analyzed the data, and drafted the manuscript. All authors approved the final manuscript version.

\section{FUNDING}

This work was supported by Natural Science Foundation of Liaoning Province (2019-MS-075), LiaoNing Revitalization Talents Program (XLYC1807124), and Dalian Technology Innovation Program (2019J13SN109).

\section{REFERENCES}

1. de Robles P, Fiest KM, Frolkis AD, Pringsheim T, Atta C, St. Germaine-Smith $\mathrm{C}$, et al. The worldwide incidence and prevalence of primary brain tumors: a systematic review and meta-analysis. Neuro Oncol. (2015) 17:776-83. doi: 10.1093/neuonc/nou283

2. Ostrom QT, Gittleman H, Truitt G, Boscia A, Kruchko C, Barnholtz-Sloan JS. CBTRUS statistical report: primary brain and other central nervous system tumors diagnosed in the United States in 2011-2015. Neuro Oncol. (2018) 20:iv1-86. doi: 10.1093/neuonc/noy131

3. Fox BD, Cheung VJ, Patel AJ, Suki D, Rao G. Epidemiology of metastatic brain tumors. Neurosurg Clin North Am. (2011) 22:1-6. doi: 10.1016/j.nec.2010.08.007

4. Cagney DN, Martin AM, Catalano PJ, Redig AJ, Lin NU, Lee EQ, et al. Incidence and prognosis of patients with brain metastases at diagnosis

of systemic malignancy: a population-based study. Neuro Oncol. (2017) 19:1511-21. doi: 10.1093/neuonc/nox077

5. Miranda-Filho A, Pineros M, Soerjomataram I, Deltour I, Bray F. Cancers of the brain and CNS: global patterns and trends in incidence. Neuro Oncol. (2017) 19:270-80. doi: 10.1093/neuonc/now166

6. McNeill KA. Epidemiology of brain tumors. Neurol Clin. (2016) 34:981-98. doi: 10.1016/j.ncl.2016.06.014

7. Shah V, Kochar P. Brain cancer: implication to disease, therapeutic strategies and tumor targeted drug delivery approaches. Recent Pat Anticancer Drug Discov. (2018) 13:70-85. doi: 10.2174/1574892812666171129142023

8. Perkins A, Liu G. Primary brain tumors in adults: diagnosis and treatment. Am Fam Physician. (2016) 93:211-7.

9. Rock K, McArdle O, Forde P, Dunne M, Fitzpatrick D, O'Neill B, et al. A clinical review of treatment outcomes in glioblastoma multiforme-the validation in a non-trial population of the results of a randomised Phase III 
clinical trial: has a more radical approach improved survival? $\mathrm{Br} J$ Radiol. (2012) 85:e729-33. doi: 10.1259/bjr/83796755

10. Dwivedi N, Shah J, Mishra V, Mohd Amin MC, Iyer AK, Tekade RK, et al. Dendrimer-mediated approaches for the treatment of brain tumor. J Biomater Sci Polym Ed. (2016) 27:557-80. doi: 10.1080/09205063.2015.1133155

11. Theodotou C, Shah AH, Hayes S, Bregy A, Johnson JN, AzizSultan MA, et al. The role of intra-arterial chemotherapy as an adjuvant treatment for glioblastoma. Br J Neurosurg. (2014) 28:438-46. doi: 10.3109/02688697.2013.877122

12. French JD, West PM, Von Amerongen FK, Magoun HW. Effects of intracarotid administration of nitrogen mustard on normal brain and brain tumors. J Neurosurg. (1952) 9:378-89. doi: 10.3171/jns.1952.9.4.0378

13. Cooke JN, Ellis JA, Hossain S, Nguyen J, Bruce JN, Joshi S. Computational pharmacokinetic rationale for intra-arterial delivery to the brain. Drug Deliv Transl Res. (2016) 6:622-9. doi: 10.1007/s13346-016-0319-6

14. Faltings L, Kulason KO, Patel NV, Wong T, Fralin S, Li M, et al. Rechallenging recurrent glioblastoma with intra-arterial bevacizumab with blood brainbarrier disruption results in radiographic response. World Neurosurg. (2019) 131:234-41. doi: 10.1016/j.wneu.2019.07.137

15. Bianciotto C, Shields CL, Iturralde JC, Sarici A, Jabbour P, Shields JA. Fluorescein angiographic findings after intra-arterial chemotherapy for retinoblastoma. Ophthalmology. (2012) 119:843-9. doi: 10.1016/j.ophtha.2011.09.040

16. Kiviniemi V, Korhonen V, Kortelainen J, Rytky S, Keinanen T, Tuovinen T, et al. Real-time monitoring of human blood-brain barrier disruption. PLoS ONE. (2017) 12:e0174072. doi: 10.1371/journal.pone.0174072

17. Mahaley MS Jr, Hipp SW, Dropcho EJ, Bertsch L, Cush S, Tirey T, et al. Intracarotid cisplatin chemotherapy for recurrent gliomas. J Neurosurg. (1989) 70:371-8. doi: 10.3171/jns.1989.70.3.0371

18. Assietti R, Olson JJ. Intra-arterial cisplatin in malignant brain tumors: incidence and severity of otic toxicity. J Neurooncol. (1996) 27:251-8. doi: 10.1007/BF00165482

19. Hochberg FH, Pruitt AA, Beck DO, DeBrun G, Davis K. The rationale and methodology for intra-arterial chemotherapy with $\mathrm{BCNU}$ as treatment for glioblastoma. J Neurosurg. (1985) 63:876-80. doi: 10.3171/jns.1985.63.6. 0876

20. Bashir R, Hochberg FH, Linggood RM, Hottleman K. Pre-irradiation internal carotid artery BCNU in treatment of glioblastoma multiforme. $J$ Neurosurg. (1988) 68:917-9. doi: 10.3171/jns.1988.68.6.0917

21. Sonoda Y, Matsumoto K, Kakuto Y, Nishino Y, Kumabe T, Tominaga T, et al. Primary CNS lymphoma treated with combined intra-arterial ACNU and radiotherapy. Acta Neurochir. (2007) 149:1183-9. discussion: 1189. doi: $10.1007 / \mathrm{s} 00701-007-1277-\mathrm{z}$

22. Ashby LS, Shapiro WR. Intra-arterial cisplatin plus oral etoposide for the treatment of recurrent malignant glioma: a phase II study. J Neurooncol. (2001) 51:67-86. doi: 10.1023/a:1006441104260

23. Dropcho EJ, Rosenfeld SS, Morawetz RB, Vitek J, Brothers M, Gorum T, et al. Preradiation intracarotid cisplatin treatment of newly diagnosed anaplastic gliomas. The CNS Cancer Consortium. J Clin Oncol. (1992) 10:452-8. doi: 10.1200/JCO.1992.10.3.452

24. Mortimer JE, Crowley J, Eyre H, Weiden P, Eltringham J, Stuckey WJ. A phase II randomized study comparing sequential and combined intraarterial cisplatin and radiation therapy in primary brain tumors. A Southwest Oncology Group study. Cancer. (1992) 69:1220-3. doi: $10.1002 /$ cncr. 2820690525

25. Stewart DJ, Belanger JMEG, Grahovac Z, Curuvija S, Gionet LR, Aitken SE, et al. Phase I study of intracarotid administration of carboplatin. Neurosurgery. (1992) 30:512-7. doi: 10.1227/00006123-199204000-00007

26. Tfayli A, Hentschel P, Madajewicz S, Manzione J, Chowhan N, Davis R, et al. Toxicities related to intraarterial infusion of cisplatin and etoposide in patients with brain tumors. J Neurooncol. (1999) 42:73-7.

27. Figueiredo EG, Faria JW, Teixeira MJ. Treatment of recurrent glioblastoma with intra-arterial BCNU [1, 3-bis (2-chloroethyl)-1-nitrosourea]. Arq Neuropsiquiatr. (2010) 68:778-82. doi: 10.1590/S0004-282X2010000500020

28. Shapiro WR, Green SB, Burger PC, Selker RG, VanGilder JC, Robertson $\mathrm{JT}$, et al. A randomized comparison of intra-arterial versus intravenous BCNU, with or without intravenous 5-fluorouracil, for newly diagnosed patients with malignant glioma. J Neurosurg. (1992) 76:772-81. doi: 10.3171/jns.1992.76.5.0772

29. Kochii M, Kitamura I, Goto T, Nishi T, Takeshima H, Saito Y, et al. Randomized comparison of intra-arterial versus intravenous infusion of ACNU for newly diagnosed patients with glioblastoma. J Neurooncol. (2000) 49:63-70.

30. Newton HB. Intra-arterial chemotherapy of primary brain tumors. Curr Treat Opt Oncol. (2005) 6:519-30. doi: 10.1007/s11864-005-0030-1

31. Imbesi F, Marchioni E, Benericetti E, Zappoli F, Galli A, Corato M, et al. A randomized phase III study: comparison between intravenous and intraarterial $\mathrm{ACNU}$ administration in newly diagnosed primary glioblastomas. Anticancer Res. (2006) 26:553-8.

32. Pardridge WM. The blood-brain barrier: bottleneck in brain drug development. NeuroRx. (2005) 2:3-14. doi: 10.1602/neurorx.2.1.3

33. Abbott NJ, Patabendige AA, Dolman DE, Yusof SR, Begley DJ. Structure and function of the blood-brain barrier. Neurobiol Dis. (2010) 37:13-25. doi: 10.1016/j.nbd.2009.07.030

34. Bhowmik A, Khan R, Ghosh MK. Blood brain barrier: a challenge for effectual therapy of brain tumors. Biomed Res Int. (2015) 2015:320941. doi: $10.1155 / 2015 / 320941$

35. Papademetriou IT, Porter T. Promising approaches to circumvent the bloodbrain barrier: progress, pitfalls and clinical prospects in brain cancer. Ther Deliv. (2015) 6:989-1016. doi: 10.4155/tde.15.48

36. Chow BW, Gu C. The molecular constituents of the blood-brain barrier. Trends Neurosci. (2015) 38:598-608. doi: 10.1016/j.tins.2015.08.003

37. Obermeier B, Daneman R, Ransohoff RM. Development, maintenance and disruption of the blood-brain barrier. Nat Med. (2013) 19:1584-96. doi: 10.1038/nm.3407

38. Meewes C, Bohuslavizki KH, Krisch B, Held-Feindt J, Henze E, Clausen M. Molecular biologic and scintigraphic analyses of somatostatin receptornegative meningiomas. J Nucl Med. (2001) 42:1338-45.

39. Ammoun S, Hanemann CO. Emerging therapeutic targets in schwannomas and other merlin-deficient tumors. Nat Rev Neurol. (2011) 7:392-9. doi: $10.1038 /$ nrneurol.2011.82

40. Dhermain FG, Hau P, Lanfermann $H$, Jacobs $A H$, van den Bent MJ. Advanced MRI and PET imaging for assessment of treatment response in patients with gliomas. Lancet Neurol. (2010) 9:906-20. doi: 10.1016/S1474-4422(10)70181-2

41. van Tellingen O, Yetkin-Arik B, de Gooijer MC, Wesseling P, Wurdinger $\mathrm{T}$, de Vries HE. Overcoming the blood-brain tumor barrier for effective glioblastoma treatment. Drug Resist Updat. (2015) 19:1-12. doi: 10.1016/j.drup.2015.02.002

42. Lamszus K, Laterra J, Westphal M, Rosen EM. Scatter factor/hepatocyte growth factor (SF/HGF) content and function in human gliomas. Int J Dev Neurosci. (1999) 17:517-30. doi: 10.1016/S0736-5748(99)00008-8

43. Hiesiger EM, Voorhies RM, Basler GA. Opening the blood-brain and bloodtumor barriers in experimental rat brain tumors: the effect of intracarotid hyperosmolar mannitol on capillary permeability and blood flow. Ann Neurol. (1986) 19:50-9. doi: 10.1002/ana.410190110

44. Cosolo W, Christophidis N. Blood-brain barrier disruption and methotrexate in the treatment of a readily transplantable intracerebral osteogenic sarcoma of rats. Cancer Res. (1987) 47:6225-8.

45. Inoue $T$, Fukui $M$, Nishio $S$, Kitamura $K$, Nagara H. Hyperosmotic blood-brain barrier disruption in brains of rats with an intracerebrally transplanted RG-C6 tumor. J Neurosurg. (1987) 66:256-63. doi: 10.3171/jns.1987.66.2.0256

46. Shapiro WR, Voorhies RM, Hiesiger EM, Sher PB, Basler GA, Lipschutz LE. Pharmacokinetics of tumor cell exposure to [14C]methotrexate after intracarotid administration without and with hyperosmotic opening of the blood-brain and blood-tumor barriers in rat brain tumors: a quantitative autoradiographic study. Cancer Res. (1988) 48:694-701.

47. Barth RF, Yang W, Rotaru JH, Moeschberger ML, Boesel CP, Soloway AH, et al. Boron neutron capture therapy of brain tumors: enhanced survival and cure following blood-brain barrier disruption and intracarotid injection of sodium borocaptate and boronophenylalanine. Int J Radiat Oncol Biol Phys. (2000) 47:209-18. doi: 10.1016/S0360-3016(00)00421-1

48. Barth RF, Yang W, Rotaru JH, Moeschberger ML, Joel DD, Nawrocky $\mathrm{MM}$, et al. Boron neutron capture therapy of brain tumors: enhanced 
survival following intracarotid injection of either sodium borocaptate or boronophenylalanine with or without blood-brain barrier disruption. Cancer Res. (1997) 57:1129-36.

49. Hsieh CH, Chen YF, Chen FD, Hwang JJ, Chen JC, Liu RS, et al. Evaluation of pharmacokinetics of 4-borono-2-F-18-fluoro-L-phenylalanine for boron neutron capture therapy in a glioma-bearing rat model with hyperosmolar blood-brain barrier disruption. J Nucl Med. (2005) 46:1858-65.

50. Yang W, Barth RF, Carpenter DE, Moeschberger ML, Goodman JH. Enhanced delivery of boronophenylalanine for neutron capture therapy by means of intracarotid injection and blood-brain barrier disruption. Neurosurgery. (1996) 38:985-92. doi: 10.1097/00006123-199605000-00027

51. Yang W, Barth RF, Rotaru JH, Boesel CP, Wilkie DA, Bresnahan JC, et al. Boron neutron capture therapy of brain tumors: functional and neuropathologic effects of blood-brain barrier disruption and intracarotid injection of sodium borocaptate and boronophenylalanine. J Neuro Oncol. (2000) 48:179-90. doi: 10.1023/a:1006410611067

52. Yang W, Barth RF, Rotaru JH, Moeschberger ML, Joel DD, Nawrocky MM, et al. Boron neutron capture therapy of brain tumors: enhanced survival following intracarotid injection of sodium borocaptate with or without blood- brain barrier disruption. Int J Radiat Oncol Biol Phys. (1997) 37:66372. doi: 10.1016/S0360-3016(96)00082-X

53. Neuwelt EA, Barnett PA, McCormick CI, Remsen LG, Kroll RA, Sexton G. Differential permeability of a human brain tumor xenograft in the nude rat: impact of tumor size and method of administration on optimizing delivery of biologically diverse agents. Clin Cancer Res. (1998) 4:1549-55.

54. Remsen LG, Trail PA, Hellstrom I, Hellstrom KE, Neuwelt EA. Enhanced delivery improves the efficacy of a tumor-specific doxorubicin immunoconjugate in a human brain tumor xenograft model. Neurosurgery. (2000) 46:704-9. doi: 10.1097/00006123-200003000-00034

55. Song X, Walczak P, He X, Yang X, Pearl MJ, Bulte JWM, et al. Salicylic acid analogues as chemical exchange saturation transfer MRI contrast agents for the assessment of brain perfusion territory and blood-brain barrier opening after intra-arterial infusion. J Cereb Blood Flow Metab. (2016) 36:1186-94. doi: $10.1177 / 0271678 \times 16637882$

56. Bullard DE, Bigner DD. Blood-brain barrier disruption in immature Fischer 344 rats. J Neurosurg. (1984) 60:743-50. doi: 10.3171/jns.1984.60.4.0743

57. Inamura T, Black KL. Bradykinin selectively opens blood-tumor barrier in experimental brain tumors. J Cereb Blood Flow Metab. (1994) 14:862-70. doi: $10.1038 / \mathrm{jcbfm} .1994 .108$

58. Nomura $T$, Inamura $T$, Black KL. Intracarotid infusion of bradykinin selectively increases blood-tumor permeability in $9 \mathrm{~L}$ and $\mathrm{C} 6$ brain tumors. Brain Res. (1994) 659:62-6. doi: 10.1016/0006-8993(94)90863-X

59. Inamura T, Nomura T, Bartus RT, Black KL. Intracarotid infusion of RMP-7, a bradykinin analog: a method for selective drug delivery to brain tumors. $J$ Neurosurg. (1994) 81:752-8. doi: 10.3171/jns.1994.81.5.0752

60. Bartus RT, Elliott PJ, Dean RL, Hayward NJ, Nagle TL, Huff MR, et al. Controlled modulation of BBB permeability using the bradykinin agonist, RMP-7. Exp Neurol. (1996) 142:14-28. doi: 10.1006/exnr.1996.0175

61. Matsukado K, Inamura T, Nakano S, Fukui M, Bartus RT, Black KL. Enhanced tumor uptake of carboplatin and survival in glioma-bearing rats by intracarotid infusion of bradykinin analog, RMP-7. Neurosurgery. (1996) 39:125-33. discussion: 133-24. doi: 10.1097/00006123-199607000-00025

62. Matsukado K, Nakano S, Bartus RT, Black KL. Steroids decrease uptake of carboplatin in rat gliomas-uptake improved by intracarotid infusion of bradykinin analog, RMP-7. J Neuro Oncol. (1997) 34:131-8. doi: 10.1007/978-3-7091-6837-0_48

63. Nakano S, Matsukado K, Black KL. Enhanced cytokines delivery and intercellular adhesion molecule 1 (ICAM-1) expression in glioma by intracarotid infusion of bradykinin analog, RMP7. Neurol Res. (1997) 19:501-8. doi: 10.1080/01616412.1997.117 40848

64. Barnett FH, Rainov NG, Ikeda K, Schuback DE, Elliott P, Kramm CM, et al. Selective delivery of herpes virus vectors to experimental brain tumors using RMP-7. Cancer Gene Ther. (1999) 6:14-20. doi: 10.1038/sj.cgt.7700003

65. Erdlenbruch B, Jendrossek V, Eibl H, Lakomek M. Transient and controllable opening of the blood-brain barrier to cytostatic and antibiotic agents by alkylglycerols in rats. Exp Brain Res. (2000) 135:417-22. doi: $10.1007 / \mathrm{s} 002210000553$
66. Erdlenbruch B, Jendrossek V, Kugler W, Eibl H, Lakomek M. Increased delivery of erucylphosphocholine to C6 gliomas by chemical opening of the blood-brain barrier using intracarotid pentylglycerol in rats. Cancer Chemother Pharmacol. (2002) 50:299-304. doi: 10.1007/s00280-002-0497-4

67. Erdlenbruch B, Alipour M, Fricker G, Miller DS, Kugler W, Eibl $\mathrm{H}$, et al. Alkylglycerol opening of the blood-brain barrier to small and large fluorescence markers in normal and C6 glioma-bearing rats and isolated rat brain capillaries. Br J Pharmacol. (2003) 140:1201-10. doi: 10.1038/sj.bjp.0705554

68. Erdlenbruch B, Schinkhof C, Kugler W, Heinemann DEH, Herms J, Eibl $\mathrm{H}$, et al. (2003). Intracarotid administration of short-chain alkylglycerols for increased delivery of methotrexate to the rat brain. $\mathrm{Br} J$ Pharmacol. 139:685-94. doi: 10.1038/sj.bjp.0705302

69. Erdlenbruch B, Kugler W, Schinkhof C, Neurath H, Eibl H, Lakomek M. Blood-brain barrier opening with alkylglycerols: biodistribution of 1-O-pentylglycerol after intravenous and intracarotid administration in rats. J Drug Target. (2005) 13:143-50. doi: 10.1080/10611860400 029085

70. Inamura T, Nomura T, Ikezaki K, Fukui M, Pollinger G, Black KL. Intracarotid histamine infusion increases blood tumour permeability in RG2 glioma. Neurol Res. (1994) 16:125-8. doi: 10.1080/01616412.1994.11740209

71. Matsukado K, Nomura T, Ikezaki K, Fukui M. Selective increase in blood-tumor barrier permeability by calcium antagonists in transplanted rat brain tumors. Acta Neurochirurg Suppl. (1994) 60:403-5. doi: 10.1007/978-3-7091-9334-1_109

72. Spigelman MK, Zappulla RA, Goldberg JD, Goldsmith SJ, Marotta D, Malis LI, et al. Effect of intracarotid etoposide on opening the blood-brain barrier. Cancer Drug Deliv. (1984) 1:207-11. doi: 10.1089/cdd.1984.1.207

73. Sugimoto S, Yamamoto YL, Nagahiro S, Diksic M. Permeability change and brain tissue damage after intracarotid administration of cisplatin studied by double-tracer autoradiography in rats. J Neuro Oncol. (1995) 24:229-40. doi: 10.1007/BF01052839

74. Mouchard-Delmas C, Gourdier B, Vistelle R, Wiczewski M. Modification of the blood-brain barrier permeability following intracarotid infusion of vinorelbine. Anticancer Res. (1995) 15:2593-6.

75. Black KL, King WA, Ikezaki K. Selective opening of the blood-tumor barrier by intracarotid infusion of leukotriene C4. J Neurosurg. (1990) 72:912-6. doi: 10.3171/jns.1990.72.6.0912

76. Chio CC, Lin SJ, Lin MT. Leukotriene E4 selectively increase the delivery of methotrexate to the C6 gliomas in rats. J Neuro Oncol. (1995) 25:89-95. doi: 10.1007/BF01057752

77. Abraham CS, Deli MA, Joo F, Megyeri P, Torpier G. Intracarotid tumor necrosis factor-alpha administration increases the blood-brain barrier permeability in cerebral cortex of the newborn pig: quantitative aspects of double-labelling studies and confocal laser scanning analysis. Neurosci Lett. (1996) 208:85-8. doi: 10.1016/0304-3940(96) $12546-5$

78. Weyerbrock A, Walbridge S, Pluta RM, Saavedra JE, Keefer LK, Oldfield EH. Selective opening of the blood-tumor barrier by a nitric oxide donor and long-term survival in rats with C6 gliomas. J Neurosurg. (2003) 99:728-37. doi: 10.3171/jns.2003.99.4.0728

79. Wang Z-H, Xue YX, Liu YH. The modulation of protein kinase A and heat shock protein 70 is involved in the reversible increase of blood-brain tumor barrier permeability induced by papaverine. Brain Res Bull. (2010) 83:367-73. doi: 10.1016/j.brainresbull.2010.08.009

80. Neuwelt EA, Hill SA, Frenkel EP, Diehl JT, Maravilla KR, Vu LH, et al. Osmotic blood-brain barrier disruption: pharmacodynamic studies in dogs and a clinical phase I trial in patients with malignant brain tumors. Cancer Treat Rep. (1981) 65(Suppl. 2):39-43.

81. Rapoport SI. Osmotic opening of the blood-brain barrier: principles, mechanism, and therapeutic applications. Cell Mol Neurobiol. (2000) 20:21730. doi: 10.1023/a:1007049806660

82. Siegal T, Rubinstein R, Bokstein F, Schwartz A, Lossos A, Shalom E, et al. In vivo assessment of the window of barrier opening after osmotic blood-brain barrier disruption in humans. J Neurosurg. (2000) 92:599-605 . doi: 10.3171/jns.2000.92.4.0599

83. Fredericks WR, Rapoport SI. Reversible osmotic opening of the blood-brain barrier in mice. Stroke. (1988) 19:266-8. doi: 10.1161/01.STR.19.2.266 
84. Pollay M. Effect of hypertonic solutions on the blood-brain barrier. Neurology. (1975) 25:852-6. doi: 10.1212/WNL.25.9.852

85. Bonstelle CT, Kori SH, Rekate H. Intracarotid chemotherapy of glioblastoma after induced blood-brain barrier disruption. AJNR Am J Neuroradiol. (1983) 4:810-2.

86. Neuwelt EA, Howieson J, Frenkel EP, Specht HD, Weigel R, Buchan CG, et al. Therapeutic efficacy of multiagent chemotherapy with drug delivery enhancement by blood-brain barrier modification in glioblastoma. Neurosurgery. (1986) 19:573-82. doi: 10.1227/00006123-198610000-00011

87. Heimberger K, Samec P, Binder H, Podreka I, Reisner T, Deecke L, et al. Blood brain barrier modification and chemotherapy. Interv Neuroradiol. (1986) 369:223-6.

88. Hori T, Muraoka K, Saito Y, Sasahara K, Inagaki H, Inoue $\mathrm{Y}$, et al. Influence of modes of ACNU administration on tissue and blood drug concentration in malignant brain tumors. J Neurosurg. (1987) 66:372-8. doi: 10.3171/jns.1987.66.3.0372

89. Neuwelt EA, Dahlborg SA. Chemotherapy administered in conjunction with osmotic blood-brain barrier modification in patients with brain metastases. J Neuro Oncol. (1987) 4:195-207. doi: 10.1007/BF00150611

90. Miyagami M, Tsubokawa T, Tazoe M, Kagawa Y. Intra-arterial ACNU chemotherapy employing 20\% mannitol osmotic blood-brain barrier disruption for malignant brain tumors. Neurol Medico Chirurgica. (1990) 30:582-90. doi: $10.2176 / \mathrm{nmc} .30 .582$

91. Markowsky SJ, Zimmerman CL, Tholl D, Soria I, Castillo R. Methotrexate disposition following disruption of the blood-brain barrier. Ther Drug Monitor. (1991) 13:24-31. doi: 10.1097/00007691-199101000-00002

92. Iwadate $\mathrm{Y}, \mathrm{Namba} \mathrm{H}$, Saegusa $\mathrm{T}$, Sueyoshi K. Intra-arterial mannitol infusion in the chemotherapy for malignant brain tumors. J Neuro Oncol. (1993) 15:185-93. doi: 10.1007/BF01053940

93. Fortin D, Gendron C, Boudrias M, Garant MP. Enhanced chemotherapy delivery by intraarterial infusion and blood-brain barrier disruption in the treatment of cerebral metastasis. Cancer. (2007) 109:751-60. doi: $10.1002 / \mathrm{cncr} .22450$

94. Doolittle ND, Miner ME, Hall WA, Siegal T, Hanson EJ, Osztie E, et al. Safety and efficacy of a multicenter study using intraarterial chemotherapy in conjunction with osmotic opening of the blood-brain barrier for the treatment of patients with malignant brain tumors. Cancer. (2000) 88:63747. doi: 10.1002/(SICI)1097-0142(20000201)88:3<637::AID-CNCR22>3.0. $\mathrm{CO} ; 2-\mathrm{Y}$

95. Fortin D, Desjardins A, Benko A, Niyonsega T, Boudrias M. Enhanced chemotherapy delivery by intraarterial infusion and blood-brain barrier disruption in malignant brain tumors: the Sherbrooke experience. Cancer. (2005) 103:2606-15. doi: 10.1002/cncr.21112

96. Jahnke K, Kraemer DF, Knight KR, Fortin D, Bell S, Doolittle ND, et al. Intraarterial chemotherapy and osmotic blood-brain barrier disruption for patients with embryonal and germ cell tumors of the central nervous system. Cancer. (2008) 112:581-8. doi: 10.1002/cncr.23221

97. Guillaume DJ, Doolittle ND, Gahramanov S, Hedrick NA, Delashaw JB, Neuwelt EA. Intra-arterial chemotherapy with osmotic bloodbrain barrier disruption for aggressive oligodendroglial tumors: results of a phase I study. Neurosurgery. (2010) 66:48-58. discussion: 58. doi: 10.1227/01.NEU.0000363152.37594.F7

98. Angelov L, Doolittle ND, Kraemer DF, Siegal T, Barnett GH, Peereboom DM, et al. Blood-brain barrier disruption and intra-arterial methotrexate-based therapy for newly diagnosed primary CNS lymphoma: a multi-institutional experience. J Clin Oncol. (2009) 27:3503-9. doi: 10.1200/JCO.2008. 19.3789

99. Zylber-Katz E, Gomori JM, Schwartz A, Lossos A, Bokstein F, Siegal T. Pharmacokinetics of methotrexate in cerebrospinal fluid and serum after osmotic blood-brain barrier disruption in patients with brain lymphoma. Clin Pharmacol Ther. (2000) 67:631-41. doi: 10.1067/mcp.2000.106932

100. Boockvar JA, Tsiouris AJ, Hofstetter CP, Kovanlikaya I, Fralin S, Kesavabhotla K, et al. Safety and maximum tolerated dose of superselective intraarterial cerebral infusion of bevacizumab after osmotic blood-brain barrier disruption for recurrent malignant glioma Clinical article. $J$ Neurosurg. (2011) 114:624-32. doi: 10.3171/2010.9.JNS101223

101. Burkhardt JK, Riina H, Shin BJ, Christos P, Kesavabhotla K, Hofstetter $\mathrm{CP}$, et al. Intra-arterial delivery of bevacizumab after blood-brain barrier disruption for the treatment of recurrent glioblastoma: progressionfree survival and overall survival. World Neurosurg. (2012) 77:130-4. doi: 10.1016/j.wneu.2011.05.056

102. Chakraborty S, Filippi CG, Burkhardt JK, Fralin S, Ray A, Wong T, et al. Durability of single dose intra-arterial bevacizumab after blood/brain barrier disruption for recurrent glioblastoma. J Exp Ther Oncol. (2016) 11:261-7.

103. Riina HA, Fraser JF, Fralin S, Knopman J, Scheff RJ, Boockvar JA. Superselective intraarterial cerebral infusion of bevacizumab: a revival of interventional neuro-oncology for malignant glioma. J Exp Ther Oncol. (2009) 8:145-50

104. Riina HA, Knopman J, Greenfield JP, Fralin S, Gobin YP, Tsiouris AJ, et al. Balloon-assisted superselective intra-arterial cerebral infusion of bevacizumab for malignant brainstem glioma. Interv Neuroradiol. (2010) 16:71-6. doi: 10.1177/159101991001600109

105. Shin BJ, Burkhardt J-K, Riina HA, Boockvar JA. Superselective intraarterial cerebral infusion of novel agents after blood-brain disruption for the treatment of recurrent glioblastoma multiforme: a technical case series. Neurosurg Clin North Am. (2012) 23:323. doi: 10.1016/j.nec.2012.01.008

106. Rajappa P, Krass J, Riina HA, Boockvar JA, Greenfield JP. Superselective basilar artery infusion of bevacizumab and cetuximab for multiply recurrent pediatric ependymoma. Interv Neuroradiol. (2011) 17:459-65. doi: $10.1177 / 159101991101700410$

107. Chakraborty S, Filippi CG, Wong T, Ray A, Fralin S, Tsiouris AJ, et al. Superselective intraarterial cerebral infusion of cetuximab after osmotic blood/brain barrier disruption for recurrent malignant glioma: phase I study. J Neuro Oncol. (2016) 128:405-15. doi: 10.1007/s11060-016-2099-8

108. Kulason KO, Schneider JR, Chakraborty S, Filippi CG, Pramanik B, Wong T, et al. Superselective intraarterial cerebral infusion of cetuximab with blood brain barrier disruption combined with Stupp Protocol for newly diagnosed glioblastoma. J Exp Ther Oncol. (2018) 12:223-9.

109. Black KL, Cloughesy T, Huang SC, Gobin YP, Zhou Y, Grous J, et al. Intracarotid infusion of RMP-7, a bradykinin analog, and transport of gallium-68 ethylenediamine tetraacetic acid into human gliomas. $J$ Neurosurg. (1997) 86:603-9. doi: 10.3171/jns.1997.86.4.0603

110. Cloughesy TF, Black KL, Gobin YP, Farahani K, Nelson G, Villablanca P, et al. Intra-arterial Cereport (RMP-7) and carboplatin: a dose escalation study for recurrent malignant gliomas. Neurosurgery. (1999) 44:270-8. discussion: 278-9. doi: 10.1097/00006123-199902000-00015

111. Chow KL, Gobin YP, Cloughesy T, Sayre JW, Villablanca JP, Viñuela F. Prognostic factors in recurrent glioblastoma multiforme and anaplastic astrocytoma treated with selective intra-arterial chemotherapy. AJNR Am J Neuroradiol. (2000) 21:471-8.

112. Qureshi AI, Suri MF, Khan J, Sharma M, Olson K, Guterman LR, et al. Superselective intra-arterial carboplatin for treatment of intracranial neoplasms: experience in 100 procedures. J Neurooncol. (2001) 51:151-8. doi: 10.1023/A:1010683128853

113. Jahnke K, Kraemer DF, Fortin D, Bell S, Doolittle ND, Knight KR, et al. Intra-arterial chemotherapy and osmotic blood-brain barrier disruption for primitive neuroectodermal tumors. J Clin Oncol. (2007) 25:581-8. doi: 10.1200/jco.2007.25.18_suppl.2046

114. Joshi S, Ergin A, Wang M, Reif R, Zhang J, Bruce JN, et al. Inconsistent blood brain barrier disruption by intraarterial mannitol in rabbits: implications for chemotherapy. J Neurooncol. (2011) 104:11-9. doi: 10.1007/s11060-010-0466-4

115. Groothuis DR, Warkne PC, Molnar P, Lapin GD, Mikhael MA. Effect of hyperosmotic blood-brain barrier disruption on transcapillary transport in canine brain tumors. J Neurosurg. (1990) 72:441-9. doi: 10.3171/jns.1990.72.3.0441

116. Fieschi C, Lenzi GL, Zanette E, Orzi F, Passero S. Effects on EEG of the osmotic opening of the blood-brain barrier in rats. Life Sci. (1980) 27:239-43. doi: 10.1016/0024-3205(80)90143-5

117. Marchi N, Angelov L, Masaryk T, Fazio V, Granata T, Hernandez N, et al. Seizure-promoting effect of blood-brain barrier disruption. Epilepsia. (2007) 48:732-42. doi: 10.1111/j.1528-1167.2007.00988.x

118. Elkassabany NM, Bhatia J, Deogaonkar A, Barnett GH, Lotto M, Maurtua M, et al. Perioperative complications of blood brain barrier disruption under general anesthesia: a retrospective review. J Neurosurg Anesthesiol. (2008) 20:45-8. doi: 10.1097/ANA.0b013e31815d5flf 
119. Ikeda M, Bhattacharjee AK, Kondoh T, Nagashima T, Tamaki N. Synergistic effect of cold mannitol and $\mathrm{Na}+/ \mathrm{Ca} 2+$ exchange blocker on bloodbrain barrier opening. Biochem Biophys Res Commun. (2002) 291:669-74. doi: 10.1006/bbrc.2002.6495

120. Kaya M, Gulturk S, Elmas L, Kalayci R, Arican N, Kocyildiz ZC, et al. The effects of magnesium sulfate on blood-brain barrier disruption caused by intracarotid injection of hyperosmolar mannitol in rats. Life Sci. (2004) 76:201-12. doi: 10.1016/j.lfs.2004.07.012

121. Schlageter KE, Molnar P, Lapin GD, Groothuis DR. Microvessel organization and structure in experimental brain tumors: microvessel populations with distinctive structural and functional properties. Microvasc Res. (1999) 58:312-28. doi: 10.1006/mvre.1999.2188

122. Ningaraj NS, Rao M, Hashizume K, Asotra K, Black KL. Regulation of blood-brain tumor barrier permeability by calcium-activated potassium channels. J Pharmacol Exp Ther. (2002) 301:838-51. doi: 10.1124/jpet.301. 3.838

123. Nakano S, Matsukado K, Black KL. Increased brain tumor microvessel permeability after intracarotid bradykinin infusion is mediated by nitric oxide. Cancer Res. (1996) 56:4027-31.

124. Sugita M, Hunt GE, Liu Y, Black KL. Nitric oxide and cyclic GMP attenuate sensitivity of the blood-tumor barrier permeability to bradykinin. Neurol Res. (1998) 20:559-63. doi: 10.1080/01616412.1998.11740564

125. Rainov NG, Dobberstein KU, Heidecke V, Dorant U, Chase M, Kramm CM, et al. Long-term survival in a rodent brain tumor model by bradykininenhanced intra-arterial delivery of a therapeutic herpes simplex virus vector. Cancer Gene Ther. (1998) 5:158-62.

126. Bartus RT. Use of Cereport (TM) (RMP-7) to increase delivery of carboplatin to gliomas: insight and parameters for intracarotid infusion via a single-lumen cannula. Drug Delivery. (1999) 6:15-21. doi: 10.1080/107175499267110

127. Rainov NG, Zimmer C, Chase M, Kramm CM, Chiocca EA, Weissleder $\mathrm{R}$, et al. Selective uptake of viral and monocrystalline particles delivered intra-arterially to experimental brain neoplasms. Human Gene Ther. (1995) 6:1543-52. doi: 10.1089/hum.1995.6.12-1543

128. Ford J, Osborn C, Barton T, Bleehen NM. A phase I study of intravenous RMP-7 with carboplatin in patients with progression of malignant glioma. Eur J Cancer. (1998) 34:1807-11. doi: 10.1016/S0959-8049(98)00155-5

129. Emerich DF, Snodgrass P, Dean R, Agostino M, Hasler B, Pink $M$, et al. Enhanced delivery of carboplatin into brain tumours with intravenous Cereport (RMP-7): dramatic differences and insight gained from dosing parameters. Br J Cancer. (1999) 80:964-70. doi: 10.1038/sj.bjc.66 90450

130. Prados MD, Schold SC Jr, Fine HA, Jaeckle K, Hochberg F, Mechtler L, et al. A randomized, double-blind, placebo-controlled, phase 2 study of RMP-7 in combination with carboplatin administered intravenously for the treatment of recurrent malignant glioma. Neuro Oncol. (2003) 5:96-103. doi: $10.1093 /$ neuonc/5.2.96

131. Samala R, Thorsheim HR, Goda S, Taskar K, Gril B, Steeg PS, et al. Vinorelbine delivery and efficacy in the MDA-MB-231BR preclinical model of brain metastases of breast cancer. Pharm Res. (2016) 33:2904-19. doi: 10.1007/s11095-016-2012-3

132. Newton HB, Page MA, Junck L, Greenberg HS. Intra-arterial cisplatin for the treatment of malignant gliomas. J Neurooncol. (1989) 7:39-45. doi: 10.1007/BF00149377

133. Newton HB, Slivka MA, Volpi C, Bourekas EC, Christoforidis GA, Baujan $\mathrm{MA}$, et al. Intra-arterial carboplatin and intravenous etoposide for the treatment of metastatic brain tumors. J Neurooncol. (2003) 61:35-44. doi: 10.1023/A:1021218207015

134. He G, Xiao X, Zou M, Zhang C, Xia S. Pemetrexed/cisplatin as firstline chemotherapy for advanced lung cancer with brain metastases: a case report and literature review. Medicine. (2016) 95:e4401. doi: 10.1097/MD.0000000000004401

135. Jahangiri A, Chin AT, Flanigan PM, Chen R, Bankiewicz K, Aghi MK. Convection-enhanced delivery in glioblastoma: a review of preclinical and clinical studies. J Neurosurg. (2017) 126:191-200. doi: 10.3171/2016.1.JNS151591
136. Stine CA, Munson JM. Convection-enhanced delivery: connection to and impact of interstitial fluid flow. Front Oncol. (2019) 9:966. doi: $10.3389 /$ fonc. 2019.00966

137. Kunwar S, Prados MD, Chang SM, Berger MS, Lang FF, Piepmeier $\mathrm{JM}$, et al. Direct intracerebral delivery of cintredekin besudotox (IL13PE38QQR) in recurrent malignant glioma: a report by the Cintredekin Besudotox Intraparenchymal Study Group. J Clin Oncol. (2007) 25:837-44. doi: 10.1200/JCO.2006.08.1117

138. Laske DW, Youle RJ, Oldfield EH. Tumor regression with regional distribution of the targeted toxin TF-CRM107 in patients with malignant brain tumors. Nat Med. (1997) 3:1362-8. doi: 10.1038/nm12 97-1362

139. Shi M, Fortin D, Sanche L, Paquette B. Convection-enhancement delivery of platinum-based drugs and Lipoplatin ${ }^{\mathrm{TM}}$ to optimize the concomitant effect with radiotherapy in F98 glioma rat model. Investig New Drugs. (2015) 33:555-63. doi: 10.1007/s10637-015-0228-4

140. White E, Bienemann A, Taylor H, Hopkins K, Cameron A, Gill S. A phase I trial of carboplatin administered by convection-enhanced delivery to patients with recurrent/progressive glioblastoma multiforme. Contemp Clin Trials. (2012) 33:320-31. doi: 10.1016/j.cct.2011.10.010

141. Carpentier A, Laigle-Donadey F, Zohar S, Capelle L, Behin A, Tibi A, et al. Phase 1 trial of a CpG oligodeoxynucleotide for patients with recurrent glioblastoma. Neuro Oncol. (2006) 8:60-6. doi: 10.1215/S1522851705 000475

142. Kunwar S, Chang SM, Prados MD, Berger MS, Sampson JH, Croteau D, et al. Safety of intraparenchymal convection-enhanced delivery of cintredekin besudotox in early-phase studies. Neurosurg Focus. (2006) 20:E15.

143. Shi M, Sanche L. Convection-enhanced delivery in malignant gliomas: a review of toxicity and efficacy. J Oncol. (2019) 2019:9342796. doi: 10.1155/2019/9342796

144. Debinski W, Tatter SB. Convection-enhanced delivery for the treatment of brain tumors. Expert Rev Neurother. (2009) 9:1519-27. doi: 10.1586/ern.09.99

145. Hynynen K. Ultrasound for drug and gene delivery to the brain. Adv Drug Deliv Rev. (2008) 60:1209-17. doi: 10.1016/j.addr.2008.03.010

146. Hynynen K, McDannold N, Vykhodtseva N, Raymond S, Weissleder R, Jolesz FA, et al. Focal disruption of the blood-brain barrier due to 260 $\mathrm{kHz}$ ultrasound bursts: a method for molecular imaging and targeted drug delivery. J Neurosurg. (2006) 105:445-54. doi: 10.3171/jns.2006.105. 3.445

147. Treat LH, McDannold N, Vykhodtseva N, Zhang Y, Tam K, Hynynen $\mathrm{K}$. Targeted delivery of doxorubicin to the rat brain at therapeutic levels using MRI-guided focused ultrasound. Int J Cancer. (2007) 121:901-7. doi: $10.1002 /$ ijc. 22732

148. Mainprize T, Lipsman N, Huang Y, Meng Y, Bethune A, Ironside S, et al. Blood-brain barrier opening in primary brain tumors with non-invasive MRguided focused ultrasound: a Clinical Safety and Feasibility Study. Sci Rep. (2019) 9:321. doi: 10.1038/s41598-018-36340-0

149. Liu HL, Hua MY, Chen PY, Chu PC, Pan CH, Yang HW, et al. Bloodbrain barrier disruption with focused ultrasound enhances delivery of chemotherapeutic drugs for glioblastoma treatment. Radiology. (2010) 255:415-25. doi: 10.1148/radiol.10090699

150. Mei J, Cheng Y, Song Y, Yang Y, Wang F, Liu Y, et al. Experimental study on targeted methotrexate delivery to the rabbit brain via magnetic resonance imaging-guided focused ultrasound. J Ultrasound Med. (2009) 28:871-80. doi: 10.7863/jum.2009.28.7.871

151. McDannold N, Clement GT, Black P, Jolesz F, Hynynen K. Transcranial magnetic resonance imaging- guided focused ultrasound surgery of brain tumors: initial findings in 3 patients. Neurosurgery. (2010) 66:323-32. doi: 10.1227/01.NEU.0000360379.95800.2F

152. Bunevicius A, McDannold NJ, Golby AJ. Focused ultrasound strategies for brain tumor therapy. Oper Neurosurg. (2019) 19:9-18. doi: 10.1093/ons/opz374

153. Pulfer SK, Gallo JM. Enhanced brain tumor selectivity of cationic magnetic polysaccharide microspheres. J Drug Target. (1998) 6:215-27. doi: $10.3109 / 10611869808997896$ 
154. Han L, Ren Y, Long L, Zhong Y, Shen C, Pu P, et al. Inhibition of C6 glioma in vivo by combination chemotherapy of implantation of polymer wafer and intracarotid perfusion of transferrin-decorated nanoparticles. Oncol Rep. (2012) 27:121-8. doi: 10.3892/or.2011.1459

155. Huynh NT, Passirani C, Allard-Vannier E, Lemaire L, Roux J, Garcion E, et al. Administration-dependent efficacy of ferrociphenol lipid nanocapsules for the treatment of intracranial 9L rat gliosarcoma. Int J Pharm. (2012) 423:55-62. doi: 10.1016/j.ijpharm.2011.04.037

156. Zhao M, Chang J, Fu X, Liang C, Liang S, Yan R, et al. Nanosized cationic polymeric magnetic liposomes significantly improves drug delivery to the brain in rats. J Drug Targeting. (2012) 20:416-21. doi: 10.3109/1061186X.2011.651726

157. Charest G, Sanche L, Fortin D, Mathieu D, Paquette B. Optimization of the route of platinum drugs administration to optimize the concomitant treatment with radiotherapy for glioblastoma implanted in the Fischer rat brain. J Neuro Oncol. (2013) 115:365-73. doi: 10.1007/s11060-013-1238-8

158. Joshi S, Singh-Moon R, Wang M, Chaudhuri DB, Ellis JA, Bruce JN, et al. Cationic surface charge enhances early regional deposition of liposomes after intracarotid injection. J Neuro Oncol. (2014) 120:489-97. doi: 10.1007/s11060-014-1584-1

159. Joshi S, Singh-Moon RP, Wang M, Chaudhuri DB, Holcomb M, Straubinger NL, et al. Transient cerebral hypoperfusion assisted intraarterial cationic liposome delivery to brain tissue. J Neuro Oncol. (2014) 118:73-82. doi: 10.1007/s11060-014-1421-6

160. Joshi S, Singh-Moon RP, Ellis JA, Chaudhuri DB, Wang M, Reif R, et al. Cerebral hypoperfusion-assisted intra-arterial deposition of liposomes in normal and glioma-bearing rats. Neurosurgery. (2015) 76:92-100. doi: 10.1227/NEU.0000000000000552

161. Singh-Moon RP, Roblyer DM, Bigio IJ, Joshi S. Spatial mapping of drug delivery to brain tissue using hyperspectral spatial frequency-domain imaging. J Biomed Opt. (2014) 19:096003. doi: 10.1117/1.JBO.19.9.096003

162. Joshi S, Cooke JR, Chan DK, Ellis JA, Hossain SS, Singh-Moon RP, et al. Liposome size and charge optimization for intraarterial delivery to gliomas. Drug Deliv Transl Res. (2016) 6:225-33. doi: 10.1007/s13346-016-0294-y

163. Nguyen J, Cooke JRN, Ellis JA, Deci M, Emala CW, Bruce JN, et al. Cationizable lipid micelles as vehicles for intraarterial glioma treatment. $J$ Neuro Oncol. (2016) 128:21-8. doi: 10.1007/s11060-016-2088-y

164. Joshi SJ, Cooke RN, Ellis JA, Emala CW, Bruce JN. Targeting brain tumors by intra-arterial delivery of cell-penetrating peptides: a novel approach for primary and metastatic brain malignancy. J Neuro Oncol. (2017) 135:497506. doi: 10.1007/s11060-017-2615-5

165. Nguyen J, Hossain SS, Cooke JRN, Ellis JA, Deci MB, Emala CW, et al. Flow arrest intra-arterial delivery of small TAT-decorated and neutral micelles to gliomas. J Neuro Oncol. (2017) 133:77-85. doi: 10.1007/s11060-017-2429-5

166. Chertok B, David AE, Yang VC. Brain tumor targeting of magnetic nanoparticles for potential drug delivery: effect of administration route and magnetic field topography. J Control Release. (2011) 155:393-9. doi: 10.1016/j.jconrel.2011.06.033

167. Chertok B, David AE, Yang VC. Magnetically-enabled and MR-monitored selective brain tumor protein delivery in rats via magnetic nanocarriers. Biomaterials. (2011) 32:6245-53. doi: 10.1016/j.biomaterials.2011.05.004

168. Wen CJ, Zhang LW, Al-Suwayeh SA, Yen TC, Fang JY. Theranostic liposomes loaded with quantum dots and apomorphine for brain targeting and bioimaging. Int J Nanomedicine. (2012) 7:1599-611. doi: $10.2147 /$ IJN.S29369

169. Cooper I, Sasson K, Teichberg VI, Schnaider-Beeri M, Fridkin M, Shechter Y. Peptide derived from HIV-1 TAT protein destabilizes a monolayer of endothelial cells in an in vitro model of the blood-brain barrier and allows permeation of high molecular weight proteins. J Biol Chem. (2012) 287:44676-83. doi: 10.1074/jbc.M112.395384

170. Tang W, Fan W, Lau J, Deng L, Shen Z, Chen X. Emerging blood-brainbarrier-crossing nanotechnology for brain cancer theranostics. Chem Soc Rev. (2019) 48:2967-3014. doi: 10.1039/C8CS00805A

171. Dedrick RL. Arterial drug infusion: pharmacokinetic problems and pitfalls. $J$ Natl Cancer Inst. (1988) 80:84-9. doi: 10.1093/jnci/80.2.84

172. Saris SC, Shook DR, Blasberg RG, Dedrick RL, Doppman JL, Bankiewicz $\mathrm{KS}$, et al. Carotid artery mixing with diastole-phased pulsed drug infusion. J Neurosurg. (1987) 67:721-5. doi: 10.3171/jns.1987.67.5.0721
173. Joshi S, Wang M, Etu JJ, Nishanian EV, Pile-Spellman J. Cerebral blood flow affects dose requirements of intracarotid propofol for electrocerebral silence. Anesthesiology. (2006) 104:290-8. discussion: 295A. doi: 10.1097/00000542-200602000-00014

174. Wang M, Etu J, Joshi S. Enhanced disruption of the blood brain barrier by intracarotid mannitol injection during transient cerebral hypoperfusion in rabbits. J Neurosurg Anesthesiol. (2007) 19:249-56. doi: 10.1097/ANA.0b013e3181453851

175. Ellis JA, Cooke J, Singh-Moon RP, Wang M, Bruce JN, Emala CW, et al. Safety, feasibility, and optimization of intra-arterial mitoxantrone delivery to gliomas. J Neuro Oncol. (2016) 130:449-54. doi: 10.1007/s11060-016-2253-3

176. Schem BC, Dahl O. Thermal enhancement of ACNU and potentiation of thermochemotherapy with ACNU by hypertonic glucose in the BT4An rat glioma. J Neuro Oncol. (1991) 10:247-52. doi: 10.1007/BF00177537

177. Natori Y, Baba T, Moriguchi M, Takeshita I, Fukui M. Effects of theophylline on the selective increases in intratumoral blood flow induced by intracarotid infusion of adenosine and adenosine triphosphate in C6 glioma-transplanted rat brains. Surg Neurol. (1992) 37:8-14. doi: 10.1016/0090-3019(92) 90058-U

178. Nomura T, Ikezaki K, Natori Y, Fukui M. Altered response to histamine in brain tumor vessels: the selective increase of regional cerebral blood flow in transplanted rat brain tumor. J Neurosurg. (1993) 79:722-8. doi: 10.3171/jns.1993.79.5.0722

179. Nomura T, Ikezaki K, Matsukado K, Fukui M. Effects of prostacyclin analogue iloprost on the regional cerebral blood flow in transplanted rat brain tumour. Neurol Res. (1993) 15:401-4. doi: 10.1080/01616412.1993.11740172

180. Hashimoto T, Young WL, Aagaard BD, Joshi S, Ostapkovich ND, PileSpellman J, et al. Adenosine-induced ventricular asystole to induce transient profound systemic hypotension in patients undergoing endovascular therapy. Dose Res Char Anesthesiol. (2000) 93:998-1001. doi: 10.1097/00000542-200010000-00021

181. Joshi S, Wang M, Etu JJ, Suckow RF, Cooper TB, Feinmark SJ, et al. Transient cerebral hypoperfusion enhances intraarterial carmustine deposition into brain tissue. J Neurooncol. (2008) 86:123-32. doi: 10.1007/s11060-0 07-9450-Z

182. Theron J, Villemure JG, Worthington C, Tyler JL. Superselective intracerebral chemotherapy of malignant tumours with BCNU. Neuroradiol Consider Neuroradiol. (1986) 28:118-25. doi: 10.1007/BF00327882

183. Charnsangavej C, Lee Y, Carrasco CH, Feun LG, Tang RA, Wright K, et al. Supraclinoid intracarotid chemotherapy using a flow-directed soft-tipped catheter. Radiology. (1985) 155:655-7. doi: 10.1148/radiology.155.3.4001366

184. Kapp JP, Ross RL, Tucker EM. Supraophthalmic carotid infusion for brain-tumor chemotherapy. J Neurosurg. (1983) 58:616-8. doi: 10.3171/jns.1983.58.4.0616

185. Tyler JL, Yamamoto YL, Diksic M, Theron J, Villemure JG, Worthington $\mathrm{C}$, et al. Pharmacokinetics of superselective intra-arterial and intravenous [11C]BCNU evaluated by PET. J Nucl Med. (1986) 27:775-80.

186. Aoki S, Terada H, Kosuda S, Shitara N, Fujii H, Suzuki K, et al. Supraophthalmic chemotherapy with long tapered catheter: distribution evaluated with intraarterial and intravenous Tc-99m HMPAO. Radiology. (1993) 188:347-50. doi: 10.1148/radiology.188.2.8327676

187. Chrousos GA, Oldfield EH, Doppman JL, Cogan DG. Prevention of ocular toxicity of carmustine (BCNU) with supraophthalmic intracarotid infusion. Ophthalmology. (1986) 93:1471-5. doi: 10.1016/S0161-6420(86) 33544-9

188. Kapp JP, Parker JL, Tucker EM. Supraophthalmic carotid infusion for brain chemotherapy. Experience with a new single-lumen catheter and maneuverable tip. J Neurosurg. (1985) 62:823-5. doi: 10.3171/jns.1985.62.6.0823

189. Kapp JP, Vance RB. Supraophthalmic carotid infusion for recurrent glioma: rationale, technique, and preliminary results for cisplatin and BCNU. J Neuro Oncol. (1985) 3:5-11. doi: 10.1007/BF00165165

190. Tamaki M, Ohno K, Niimi Y, Aoyagi M, Nagashima G, Ichimura K, et al. Parenchymal damage in the territory of the anterior choroidal artery following supraophthalmic intracarotid administration of CDDP for treatment of malignant gliomas. J Neuro Oncol. (1997) 35:65-72. doi: 10.1023/A:1005847115488 
191. Vance RB, Kapp JP. Supraophthalmic carotid infusion with low dose cisplatin and BCNU for malignant glioma. J Neuro Oncol. (1986) 3:287-90. doi: 10.1007/BF00165576

192. Debrun GM, Davis KR, Hochberg FH. Superselective injection of BCNU through a latex calibrated-leak balloon. AJNR Am J Neuroradiol. (1983) 4:399-400.

193. Larner JM, Kersh CR, Constable WC, Kline P, Ferguson R, Short $\mathrm{R}$, et al. Phase I/II trial of superselective arterial 5-FU infusion with concomitant external beam radiation for patients with either anaplastic astrocytoma or glioblastoma multiforme. Am J Clin Oncol. (1991) 14:514-8. doi: 10.1097/00000421-199112000-00010

194. Jeon JY, Kovanlikaya I, Boockvar JA, Mao X, Shin B, Burkhardt JK, et al. Metabolic response of glioblastoma to superselective intra-arterial cerebral infusion of bevacizumab: a proton MR spectroscopic imaging study. AJNR Am J Neuroradiol. (2012) 33:2095-102. doi: 10.3174/ajnr.A3091

195. Riina HA, Burkhardt JK, Santillan A, Bassani L, Patsalides A, Boockvar JA. Short-term clinico-radiographic response to super-selective intraarterial cerebral infusion of bevacizumab for the treatment of vestibular schwannomas in neurofibromatosis type 2. Interv Neuroradiol. (2012) 18:127-32. doi: 10.1177/159101991201800201

196. Suzuki S, Kurata A, Takagi H, Nakahara K, Oka H, Miyasaka Y, et al. Superselective arterial chemotherapy for inoperable metastases in the dura mater and cranium. Interv Neuroradiol. (2002) 8:121-5. doi: $10.1177 / 159101990200800203$

197. Rong J, Chunhua M, Yuan L, Ning M, Jinduo L, Bin W, et al. Clinical interrogation and application of super-selective intracranial artery infusion chemotherapy for lung cancer patients with brain metastases. Indian $J$ Cancer. (2015) 52(Suppl. 1):e22-5. doi: 10.4103/0019-509X.168951

198. Bernhardt D, Adeberg S, Bozorgmehr F, Opfermann N, HoernerRieber J, Konig L, et al. Outcome and prognostic factors in patients with brain metastases from small-cell lung cancer treated with whole brain radiotherapy. J Neuro Oncol. (2017) 134:205-12. doi: 10.1007/s11060-017-2510-0

199. Kepka L, Cieslak E, Bujko K, Fijuth J, Wierzchowski M. Results of the whole-brain radiotherapy for patients with brain metastases from lung cancer: the RTOG RPA intra-classes analysis. Acta Oncol. (2005) 44:389-98. doi: 10.1080/02841860510029699

200. Ginos JZ, Cooper AJ, Dhawan V, Lai JC, Strother SC, Alcock N, et al. $[13 \mathrm{~N}]$ cisplatin PET to assess pharmacokinetics of intra-arterial versus intravenous chemotherapy for malignant brain tumors. J Nucl Med. (1987) 28:1844-52.

201. Di Chiro G, Oldfield E, Wright DC, De Michele D, Katz DA, Patronas NJ, et al. Cerebral necrosis after radiotherapy and/or intraarterial chemotherapy for brain tumors: PET and neuropathologic studies. AJR Am J Roentgenol. (1988) 150:189-97. doi: 10.2214/ajr.150.1.189

202. Langen KJ, Roosen N, Kuwert T, Herzog H, Kiwit JC, Rota Kops E, et al. Early effects of intra-arterial chemotherapy in patients with brain tumours studied with PET: preliminary results. Nucl Med Commun. (1989) 10:779-90. doi: 10.1097/00006231-198911000-00002

203. Sasajima T, Mineura K, Sasaki J, Kowada M, Tomura N, Hatazawa J, et al. Positron emission tomographic assessment of cerebral hemocirculation and glucose metabolism in malignant glioma following treatment with intracarotid recombinant human tumor necrosis factor-alpha. J Neuro Oncol. (1995) 23:67-73. doi: 10.1007/BF01058461

204. Tomura N, Hirano H, Watanabe O, Kato K, Sasaki K, Watarai J, et al. Preliminary results with technetium-99m MIBI SPECT imaging in patients with brain tumors: correlation with histological and neuroradiological diagnoses and therapeutic response. Comput Med Imaging Graph. (1997) 21:293-8. doi: 10.1016/S0895-6111(97)00026-8

205. Namba H, Kobayashi S, Iwadate Y, Saegusa T, Sato A, Watanabe Y, et al. Assessment of the brain areas perfused by superselective intraarterial chemotherapy using single photon emission computed tomography with technetium-99m-hexamethyl-propyleneamine oxime-technical note. Neurol Medico Chirurgica. (1994) 34:832-5. doi: 10.2176/nmc.34.832

206. Shani J, Bertram J, Russell C, Dahalan R, Chen DC, Parti R, et al. Noninvasive monitoring of drug biodistribution and metabolism: studies with intraarterial Pt-195m-cisplatin in humans. Cancer Res. (1989) 49:1877-81
207. Tomura N, Hashimoto M, Sashi R, Hirano H, Kobayashi M, Hirano Y, et al. Superselective angio-CT of brain tumors. AJNR Am J Neuroradiol. (1996) 17:1073-80.

208. Hirai T, Korogi Y, Ono K, Yamashita Y. Evaluation of vascular supply with angio-computed tomography during intra-arterial chemotherapy for brain tumors. Cardiovasc Interv Radiol. (2005) 28:354-7. doi: 10.1007/s00270-003-0094-x

209. Arnold DL, Shoubridge EA, Emrich J, Feindel W, Villemure JG. Early metabolic changes following chemotherapy of human gliomas in vivo demonstrated by phosphorus magnetic resonance spectroscopy. Invest Radiol. (1989) 24:958-61. doi: 10.1097/00004424-198912000-00007

210. Arnold DL, Shoubridge EA, Feindel W, Villemure JG. Metabolic changes in cerebral gliomas within hours of treatment with intra-arterial BCNU demonstrated by phosphorus magnetic resonance spectroscopy. Can J Neurol Sci. (1987) 14:570-5.

211. Yoshikawa T, Aoki S, Hori M, Nambu A, Kumagai H, Araki T. Timeresolved two-dimensional thick-slice magnetic resonance digital subtraction angiography in assessing brain tumors. Eur Radiol. (2000) 10:736-44. doi: 10.1007/s003300050996

212. Zawadzki M, Walecki J, Kostkiewicz B, Kostyra K, Pearl MS, Solaiyappan M, et al. Republished: real-time MRI guidance for intra-arterial drug delivery in a patient with a brain tumor: technical note. J Neurointerv Surg. (2019) 11:e3. doi: 10.1136/neurintsurg-2018-014469.rep

213. Chen S, Ji X, Liu M, Xia Z, Zheng H, Yin Q, et al. The value of MRI in evaluating the efficacy and complications with the treatment of intraarterial chemotherapy for retinoblastoma. Oncotarget. (2017) 8:38413-25. doi: 10.18632/oncotarget.16423

214. Kim B, Kim K, Im KH, Kim JH, Lee JH, Jeon P, et al. Multiparametric MR imaging of tumor response to intraarterial chemotherapy in orthotopic xenograft models of human metastatic brain tumor. J Neuro Oncol. (2016) 127:243-51. doi: 10.1007/s11060-015-2041-5

215. Cao M, Mao J, Duan X, Lu L, Zhang F, Lin B, et al. In vivo tracking of the tropism of mesenchymal stem cells to malignant gliomas using reporter gene-based MR imaging. Int J Cancer. (2018) 142:1033-46. doi: $10.1002 / \mathrm{ijc} .31113$

216. Qiao Y, Gumin J, MacLellan CJ, Gao F, Bouchard R, Lang FF, et al Magnetic resonance and photoacoustic imaging of brain tumor mediated by mesenchymal stem cell labeled with multifunctional nanoparticle introduced via carotid artery injection. Nanotechnology. (2018) 29:165101. doi: 10.1088/1361-6528/aaaf16

217. Terada T, Nambu K, Hyotani G, Miyamoto K, Tsuura M, Nakamura Y, et al. A method for quantitative measurement of cerebral vascular permeability using X-ray CT and iodinated contrast medium. Neuroradiology. (1992) 34:290-6. doi: 10.1007/BF00588184

218. Boxerman JL, Shiroishi MS, Ellingson BM, Pope WB. Dynamic susceptibility contrast MR imaging in glioma: review of current clinical practice. Magnetic Resonance Imaging Clin North Am. (2016) 24:649-70. doi: 10.1016/j.mric.2016.06.005

219. Thomsen HS, Morcos SK, Almén T, Bellin MF, Bertolotto M, Bongartz G, et al. Nephrogenic systemic fibrosis and gadolinium-based contrast media: updated ESUR Contrast Medium Safety Committee guidelines. Eur Radiol. (2013) 23:307-18. doi: 10.1007/s00330-012-2597-9

220. Xu Q, Liu Q, Ge H, Ge X, Wu J, Qu J, et al. Tumor recurrence versus treatment effects in glioma A comparative study of three dimensional pseudo-continuous arterial spin labeling and dynamic susceptibility contrast imaging. Medicine. (2017) 96:e9332. doi: 10.1097/MD.0000000000 009332

221. Zhou L, Wang Y, Pinho MC, Pan E, Xi Y, Maldjian JA, et al. Intrasession reliability of arterial spin-labeled MRI-measured noncontrast perfusion in glioblastoma at $3 \mathrm{~T}$. Tomography. (2020) 6:139-47. doi: $10.18383 /$ j.tom. 2020.00010

222. Turski P, Kalinke T, Strother L, Perman W, Scott G, Kornguth S. Magnetic resonance imaging of rabbit brain after intracarotid injection of large multivesicular liposomes containing paramagnetic metals and DTPA. Magnetic Resonance Med. (1988) 7:184-96. doi: 10.1002/mrm.19100 70206

223. Chertok B, Moffat BA, David AE, Yu F, Bergemann C, Ross BD, et al. Iron oxide nanoparticles as a drug delivery vehicle for MRI monitored 
magnetic targeting of brain tumors. Biomaterials. (2008) 29:487-96. doi: 10.1016/j.biomaterials.2007.08.050

224. Mehta RV. Synthesis of magnetic nanoparticles and their dispersions with special reference to applications in biomedicine and biotechnology. Mater Sci Eng C Mater Biol Appl. (2017) 79:901-16. doi: 10.1016/j.msec.2017.05.135

225. Lübbe AS, Bergemann C, Huhnt W, Fricke T, Riess H, Brock JW, et al. Preclinical experiences with magnetic drug targeting: tolerance and efficacy. Cancer Res. (1996) 56:4694-701.

226. Lundberg J, Jussing E, Liu Z, Meng Q, Rao M, Samen E, et al. Safety of intra-arterial injection with tumor-activated $\mathrm{T}$ cells to the rabbit brain evaluated by MRI and SPECT/CT. Cell Transplant. (2017) 26:283-92. doi: $10.3727 / 096368916$ X693347

227. Cohen AR, Pietronigro DD, Cravioto H, Flamm ES. Effect of difluoromethylornithine on the antiglioma therapeutic efficacy of intra-arterial BCNU. J Neurosurg. (1986) 65:671-8. doi: 10.3171/jns.1986.65.5.0671

228. Resio MJ, DeVroom HL. Spiromustine and intracarotid artery cisplatin in the treatment of glioblastoma multiforme. J Neurosci Nurs. (1986) 18:13-22. doi: 10.1097/01376517-198602000-00006

229. Stewart DJ, Dahrouge S, Wee M, Aitken S, Hugenholtz H. Intraarterial cisplatin plus intravenous doxorubicin for inoperable recurrent meningiomas. J Neuro Oncol. (1995) 24:189-94. doi: 10.1007/BF01078489

230. Watne K, Hannisdal E, Nome O, Hager B, Wester K, Heier M, et al. Combined intra-arterial chemotherapy followed by radiation in astrocytomas. J Neuro Oncol. (1992) 14:73-80. doi: 10.1007/BF00170947

231. Schem BC, Krossnes BK. Enhancement of ACNU treatment of the BT4An rat glioma by local brain hyperthermia and intra-arterial drug administration. Eur J Cancer. (1995) 31A:1869-74. doi: 10.1016/0959-8049(95)00381-R

232. Morita K, Tanaka R, Kakinuma K, Takahashi H, Motoyama H. Combination therapy of rat brain tumours using localized interstitial hyperthermia and intra-arterial chemotherapy. Int J Hyperthermia. (2003) 19:204-12. doi: 10.1080/02656730210147295

233. Uzuka T, Takahashi H, Tanaka R. Interstitial hyperthermia with intra-arterial injection of adriamycin for malignant glioma. Neurol Medico Chirurgica. (2006) 46:19-23. discussion: 23. doi: 10.2176/nmc.46.19

234. Rodriguez A, Zugbi S, Requejo F, Deu A, Sampor C, Sgroi M, et al. Combined high-dose intra-arterial and intrathecal chemotherapy for the treatment of a case of extraocular retinoblastoma. Pediatric Blood Cancer. (2018) 65:e27385. doi: 10.1002/pbc.27385

235. Greenberg HS, Chandler WF, Diaz RF, Ensminger WD, Junck L, Page MA, et al. Intra-arterial bromodeoxyuridine radiosensitization and radiation in treatment of malignant astrocytomas. J Neurosurg. (1988) 69:500-5. doi: 10.3171 /jns. 1988.69 .4 .0500

236. Liu SK, Jakowatz JG, Pollack RB, Ceraldi C, Yamamoto R, Dett C, et al. Effects of intracarotid and intravenous infusion of human TNF and LT on established intracerebral rat gliomas. Lymphokine Cytokine Res. (1991) 10:189-94.

237. Yoshida J, Wakabayashi T, Mizuno M, Sugita K, Yoshida T, Hori S, et al. Clinical effect of intra-arterial tumor necrosis factor-alpha for malignant glioma. J Neurosurg. (1992) 77:78-83. doi: 10.3171/jns.1992.77.1.0078

238. Debinski W, Obiri NI, Powers SK, Pastan I, Puri RK. Human glioma cells overexpress receptors for interleukin 13 and are extremely sensitive to a novel chimeric protein composed of interleukin 13 and pseudomonas exotoxin. Clin Cancer Res. (1995) 1:1253-8.

239. Sampson JH, Akabani G, Archer GE, Berger MS, Coleman RE, Friedman $\mathrm{AH}$, et al. Intracerebral infusion of an EGFR-targeted toxin in recurrent malignant brain tumors. Neuro Oncol. (2008) 10:320-9. doi: 10.1215/15228517-2008-012

240. Abe T, Wakimoto H, Bookstein R, Maneval DC, Chiocca EA, Basilion JP. Intra-arterial delivery of p53-containingadenoviral vector into experimental brain tumors. Cancer Gene Ther. (2002) 9:228-35. doi: 10.1038/sj.cgt.7700437

241. Koga H, Inamura T, Ikezaki K, Samoto K, Matsukado K, Fukui M. Selective transvascular delivery of oligodeoxynucleotides to experimental brain tumors. J Neuro Oncol. (1999) 43:143-51. doi: 10.1023/A:1006210901856

242. Barnett FH, Scharer-Schuksz M, Wood M, Yu X, Wagner TE, Friedlander M. Intra-arterial delivery of endostatin gene to brain tumors prolongs survival and alters tumor vessel ultrastructure. Gene Ther. (2004) 11:1283-9. doi: 10.1038/sj.gt.3302287

243. Liu R, Martuza RL, Rabkin SD. Intracarotid delivery of oncolytic HSV vector G47Delta to metastatic breast cancer in the brain. Gene Ther. (2005) 12:647-54. doi: 10.1038/sj.gt.3302445

244. Foley CP, Rubin DG, Santillan A, Sondhi D, Dyke JP, Gobin YP, et al. Intra-arterial delivery of $\mathrm{AAV}$ vectors to the mouse brain after mannitol mediated blood brain barrier disruption. J Control Release. (2014) 196:71-8. doi: 10.1016/j.jconrel.2014.09.018

245. Ji N, Weng D, Liu C, Gu Z, Chen S, Guo Y, et al. Adenovirus-mediated delivery of herpes simplex virus thymidine kinase administration improves outcome of recurrent high-grade glioma. Oncotarget. (2016) 7:4369-78. doi: 10.18632/oncotarget.6737

246. Chiocca EA, Abbed KM, Tatter S, Louis DN, Hochberg FH, Barker F, et al. A phase I open-label, dose-escalation, multi-institutional trial of injection with an E1B-Attenuated adenovirus, ONYX-015, into the peritumoral region of recurrent malignant gliomas, in the adjuvant setting. Mol Ther. (2004) 10:958-66. doi: 10.1016/j.ymthe.2004. 07.021

247. Papanastassiou V, Rampling R, Fraser M, Petty R, Hadley D, Nicoll J, et al. The potential for efficacy of the modified (ICP 34.5(-)) herpes simplex virus HSV1716 following intratumoural injection into human malignant glioma: a proof of principle study. Gene Ther. (2002) 9:398-406. doi: $10.1038 /$ sj.gt.3301664

248. Geoerger B, Tang CB, Cesano A, Visonneau S, Marwaha S, Judy KD, et al. Antitumor activity of a human cytotoxic T-cell line (TALL104) in brain tumor xenografts. Neuro Oncol. (2000) 2:103-13. doi: 10.1093/neuonc/2.2.103

249. Weilemann F, Steinmetz A, Kirsch M, Buttler A, Kunze S, Kuhlisch E, et al. Prevention of brain metastasis formation by local expression of interleukin4 or hemagglutinin antigen. Zentralblatt Neurochirurgie. (2003) 64:65-70. doi: $10.1055 / \mathrm{s}-2003-40374$

250. Yong RL, Shinojima N, Fueyo J, Gumin J, Vecil GG, Marini FC, et al. Human bone marrow-derived mesenchymal stem cells for intravascular delivery of oncolytic adenovirus Delta24-RGD to human gliomas. Cancer Res. (2009) 69:8932-40. doi: 10.1158/0008-5472.CAN-083873

251. Herrmann AM, Meckel S, Gounis MJ, Kringe L, Motschall E, Mulling C, et al. Large animals in neurointerventional research: a systematic review on models, techniques and their application in endovascular procedures for stroke, aneurysms and vascular malformations. J Cereb Blood Flow Metab. (2019) 39:375-94. doi: 10.1177/0271678X19827446

Conflict of Interest: The authors declare that the research was conducted in the absence of any commercial or financial relationships that could be construed as a potential conflict of interest.

Copyright $\odot 2020$ Huang, Boltze and Li. This is an open-access article distributed under the terms of the Creative Commons Attribution License (CC BY). The use, distribution or reproduction in other forums is permitted, provided the original author(s) and the copyright owner(s) are credited and that the original publication in this journal is cited, in accordance with accepted academic practice. No use, distribution or reproduction is permitted which does not comply with these terms. 